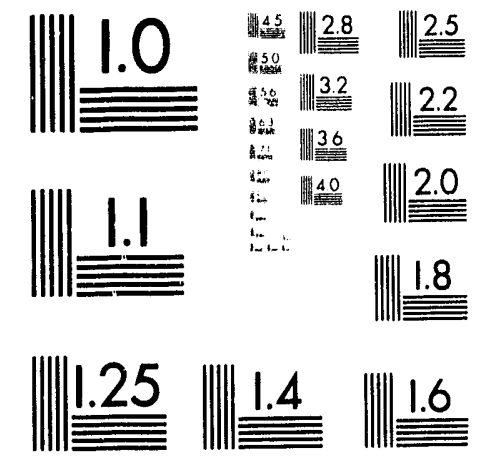



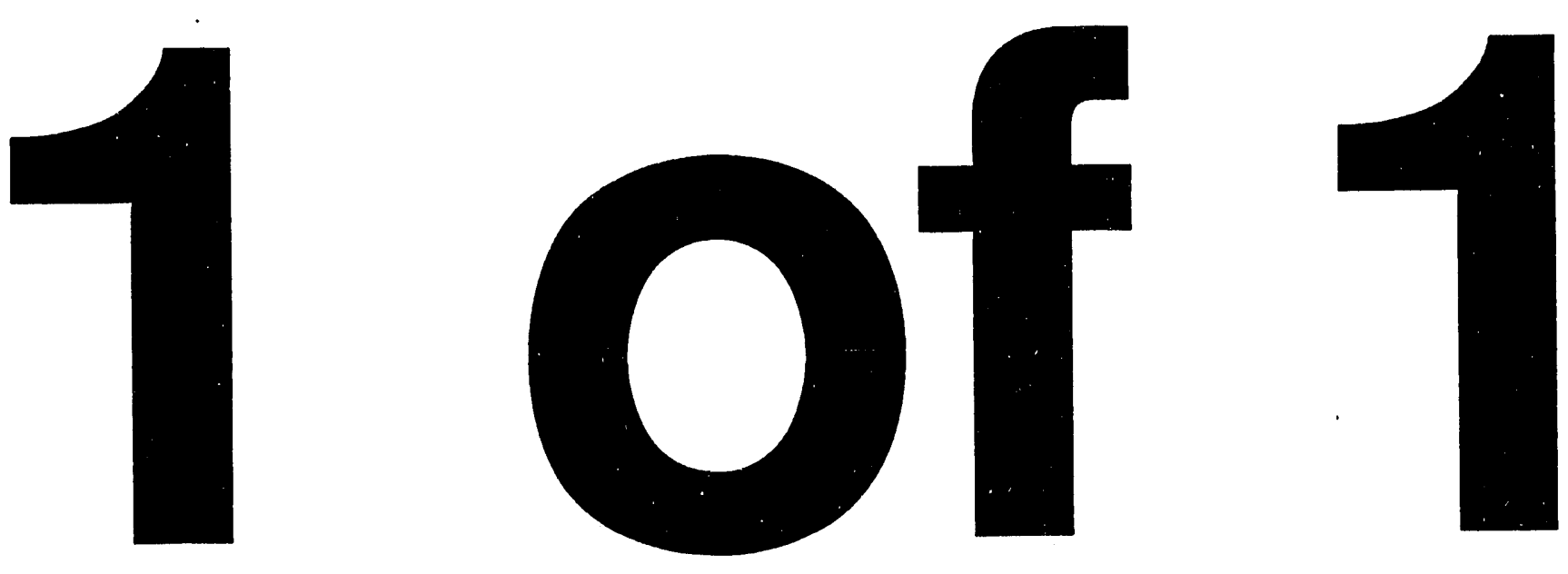


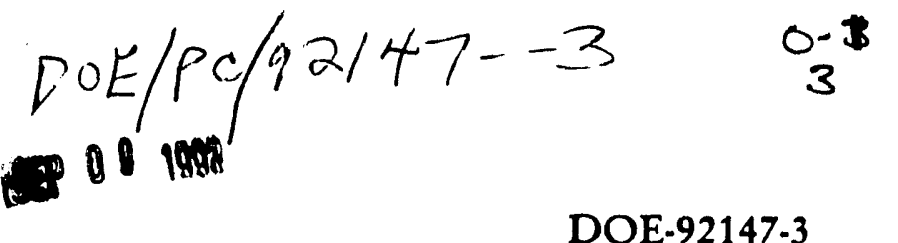

\section{CATALYTIC MULTI-STAGE LIQUEFACTION OF COAL}

THIRD QUARTERLY REPORT FOR THE PERIOD

1 APRIL 1993 - 31 JUNE 1993

A. G. Comolli

E.S. Johanson

L.K. Lee

V.R. Pradhan

R. H. Stalzer

\section{FINAL}

WORK PERFORMED UNDER CONTRACT

DE-AC22-93PC92147

HYDROCARBON RESEARCH, INC.

100 OVERLOOK CENTER, SUITE 400

PRINCETON, NJ 08540

JULY 1993 
CATALYTIC MULTI-STAGE LIQUEFACTION OF COAL

THIRD QUARTERLY REPORT FOR THE PERIOD

1 APRIL 1993 - 31 JUNE 1993
A. G. Comolli
E.S. Johanson
L.K. Lee
V.R. Pradhan
R. H. Stalzer

FINAL

WORK PERFORMED UNDER CONTRACT

DE-AC22-93PC92147

HYDROCARBON RESEARCH, INC.

100 OVERLOOK CENTER, SUITE 400

PRINCETON, NJ 08540

JULY 1993 


\title{
PRINTED IN THE UNITED STATES OF AMERICA
}

\author{
AVAILABLE FROM: \\ National Technical Information Center \\ U.S. Department of Energy \\ 5285 Port Royal Road \\ Springfield, Virginia 22161
}

This report was prepared as an account of work sponsored by the United States Government. Neither the United States nor the United States Department of Energy, nor any of their employees, makes any warranty, expressed or implied, or assumes any legal liability or responsibility for the accuracy, completeness, or usefulness of any information, apparatus product, or process disclosed, or represents that its use would not infringe privately owned rights. Reference herein to any specific commercial product, process, or service by trade name, mark, manufacturer, or otherwise, does not necessarily constitute or imply its endorsement, recommendations, or favoring by the United States Government or any agency thereof. The views and opinions of authors expressed herein do not necessarily state or reflect those of the United States Government or any agency thereof. 


\section{TABLE OF CONTENTS}

Page No.

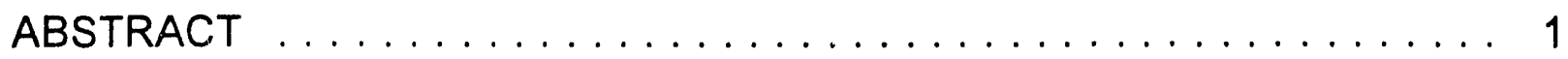

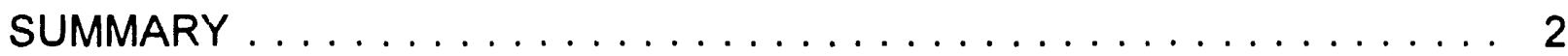

INTRODUCTION $\ldots \ldots \ldots \ldots \ldots \ldots \ldots \ldots \ldots \ldots \ldots \ldots \ldots$

Task 2 - Laboratory Scale Studies ...................... 4

Effect of Surfactant on Conversion Levels with an Equilibrium Catalyst ..................... 4

Solvent Quality Determination on Recycle Oils from CMSL-2 ............................ 5

Laboratory Support for CMSL-3 . . . . . . . . . . . . . . . 5 Effect of Different Catalysts/Promoters on Water-Gas Shift Conversion ...................... 10

Task 3 - Bench-Scale Studies ........................ 13

Run CMSL-2 - Lower Solvent-to-Coal Ratio . . . . . . . . . . . . 13

Run CMSL-3 - Effect of Synthesis Gas . . . . . . . . . . . . . . 36

Task 4 - Technical Assessment $\ldots \ldots \ldots \ldots \ldots \ldots \ldots \ldots . \ldots . \ldots . \ldots$

Task 5 - Project Management ...................... 38 


\section{LIST OF TABLES}

Page No.

Table 1 Effect of Surfactant on Conversion Levels with an

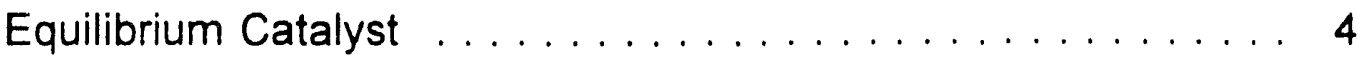

Table 2 Effect of Promoters/Catalysts on Coal Conversion in Microautoclave Tests $\mathrm{CL}-1$ thru $\mathrm{CL}-18$ with $50 / 50 \mathrm{CO} / \mathrm{H}_{2}$ Feed Mixture

Table 3 Effect of Different Catalyst/Promoters on Coal Liquefaction under Water-Gas Shift Conditions . . . . . . . . . . . . . . . . . . 9

Table 4 Effect of Different Catalysts/Promoters on Water-Gas Shift Conversion . . . . . . . . . . . . . . . . . . 10

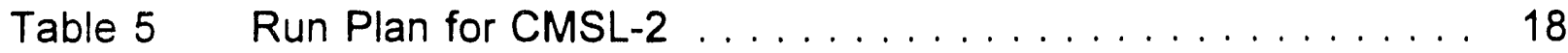

Table 6 Operations Summary and Process Performance for CMSL-2

Table 7 Comparison of Process Performance for Period No. 4 During Two Bench CTSL Runs Using Same Catalyst (Shell-317 1/32") Extrudates but Different Solvent-to-Coal Ratios

Table 8 Comparison of Two CTSL Bench Runs . . . . . . . . . . . . 21

Table 9 Comparison of Recycle Oil Properties for Three Bench Runs, I-18, CC-16, and CMSL-2

Table 10 Comparison of Two CTSL Bench Runs: 227-76 (CC-16) with Akzo AO-60 Catalyst and 227-78 9CMSL-2) with Shell-317 Catalyst to Demonstrate the Effect of Solventto-Coal Ratios on Process Performance . . . . . . . . . . . . . 23

Table 11 Comparison of Recycle Oil Properties for Three Bench Runs, I-18, CC-16, and CMSL-2 . . . . . . . . . 24

Table 12 Run Plan for the Bench Run CMSL-3 . . . . . . . . . . . . . . 37 


\section{LIST OF FIGURES}

\section{Page No.}

Figure 1 Solvent Quality of the Recycle Oil . . . . . . . . . . . 12

Figure 2 CMSL-3: Laboratory Support . . . . . . . . . . . . . 25

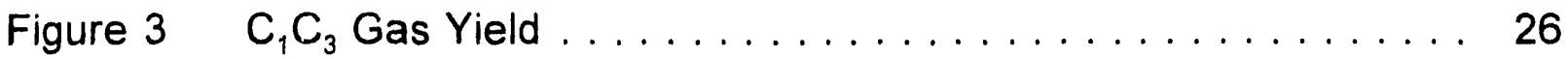

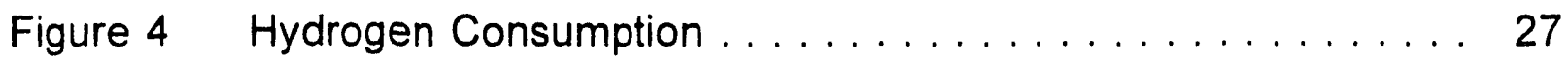

Figure 5 Hydrodenitrogenation $\ldots \ldots \ldots \ldots \ldots \ldots \ldots \ldots \ldots$

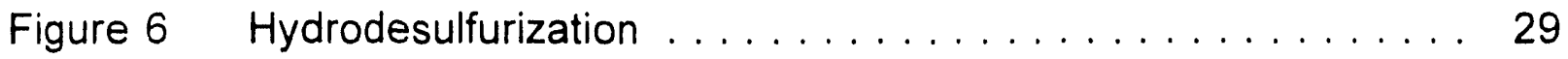

Figure $7 \quad \mathrm{C}_{4}-975^{\circ} \mathrm{F}$ Distillate Yield $\ldots \ldots \ldots \ldots \ldots \ldots \ldots \ldots$

Figure 8 Distillate Selectivity $\ldots \ldots \ldots \ldots \ldots \ldots \ldots \ldots \ldots \ldots$

Figure 9 Catalyst Age Vs PFL Properties $\ldots \ldots \ldots \ldots \ldots \ldots \ldots$

Figure 10 Comparison of Distillate Selectivity

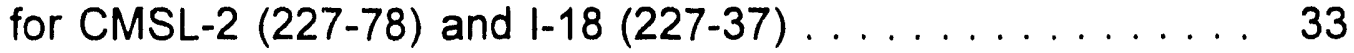

Figure 11 Comparison of Distillate Selectivity

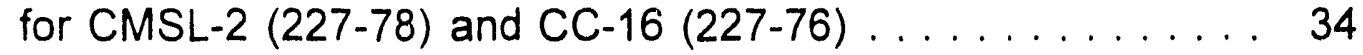

Figure 12 Comparison of Three Bench Runs . . . . . . . . . . . . 35 


\begin{abstract}
This quarterly report covers the activities of Catalytic Multi-Stage Liquefaction of Coal during the Period April 1 - June 30, 1993, at Hydrocarbon Research, Inc. in Lawrenceville and Princeton, New Jersey. This DOE Contract Period is from December 8, 1992 to December 7, 1994.

The overall objective of this program is to produce liquid fuels from coal by direct liquefaction at a cost that is competitive with conventional fuels. Specifically, this continuous bench-scale program contains provisions to examine new ideas in areas such as: low temperature pretreatments, more effective catalysts, on-line hydrotreating, new coal feedstocks, other hydrogen sources, more concentrated coal feeds and other highly responsive process improvements while assessing the design and economics of the bench-scale results.

This quarterly report covers work on Laboratory Scale Studies, Continuous BenchScale Operations, Technical Assessment and Project Management.
\end{abstract}




\section{SUMMARY}

Laboratory Scale and Bench-Scale studies continued in this quarter.

The effect of sodium lignolsulfonate, a JPL-recommended surfactant, was determined on coal and resid conversion levels in the presence of an equilibrium catalyst. A small effect of surfactant additive was observed on coal and resid conversions but only at low temperatures $\left(750^{\circ} \mathrm{F}\right)$. The quality of the recycle oil (PFL) generated during different Periods of the Bench Run, CMSL-2, was determined using the Standard Solvent Qualification Tests in a microautoclave. Laboratory support research for the upcoming Bench Run, CMSL-3, was also conducted. This included the determination of the most effective (and suitable) catalyst promoter (additive) for the Water-Gas Shift reaction, responsible for generating activated $\mathrm{H}_{2}$ during coal liquefaction with synthesis gas in the first stage. Based on the microautoclave screening studies, ammonium heptamolybdate (with 3 W\% DMDS added) was selected as a promoter or additive for the first stage reactor in the upcoming Bench Run CMSL-3.

The second bench-scale run, CMSL-2, for studying the effect of lower solvent-tocoal ratios (0.9-1.1) and the effect of a surfactant additive on coal liquefaction, was completed during this quarter. Both the product yields and quality were influenced positively as an effect of processing slurries with high coal concentrations. The overall Run operations also went on smoothly at these low solvent-to-coal ratios (0.9-1.1). Sodium lignolsulfonate, a surfactant additive developed by the Jet Propulsion Laboratory, did not have any effect either on the conversion levels or the product yields and quality under the conditions of the Bench Run CMSL-2.

A Run Plan for the next bench run, CMSL-3, to evaluate the effect of using synthesis gas on liquefaction of a high-moisture content sub-bituminous coal, under different reaction severity conditions, is also presented.

The preliminary results of the screening studies carried out to examine the economics of using dispersed vs. supported catalyst and that of using synthesis gas vs. pure hydrogen in the first stage reactor, are briefly addressed in this report. 


\section{INTRODUCTION}

This is the third progress report of a two-year contract to evaluate novel process concepts for Direct Coal Liquefaction using the Catalytic Multi-Stage Process. The primary objective is :

- To produce liquid fuels from direct coal liquefaction at a cost that is competitive with conventional fuels.

The program consists of five Tasks:

Task 1 Management Plan

Task 2 Laboratory Studies

Task 3 Bench-Scaie Studies

Task $4 \quad$ Technical Assessment

Task 5 Project Management/Administration/Environmental 
TASK 2 - LABORATORY SCALE STUDIES

(i) Effect of Surfactant on Conversion Levels with an Equilibrium Catalyst:

Objectives: $\quad$ To determine the effect of addition of $2 \mathrm{~W} \%$ (relative to coal) of sodium lignolsulfonate (a surfactant) on coal conversion levels in the preserice of an recovered catalyst (with equilibrium carbon content $=15 \mathrm{~W} \%$ )

Common Conditions: Catalyst : Recovered Shell-317 from Stage 2 of Bench

$\mathrm{H}_{2}$ :

Run 227-77 $2.0 \mathrm{~g}$

Coal(Dry): $2.0 \mathrm{~g}$

Solvent: $\quad 8.0 \mathrm{~g}(\mathrm{~L}-769)$

Results:

Table 1

Effect of Surfactant on Conversion Levels with an Equilibrium Catalyst

\begin{tabular}{||c|c|c|c|c|c||}
\hline \hline Test No. & Temperature, ${ }^{\circ} \mathrm{F}$ & $\begin{array}{c}\text { Time, } \\
\text { minutes }\end{array}$ & $\begin{array}{c}\text { Surfactant, } \\
\mathrm{gm}\end{array}$ & $\begin{array}{c}\% \text { Coal } \\
\text { Conversion }\end{array}$ & $\begin{array}{c}\% \text { Resid } \\
\text { Conversion }\end{array}$ \\
\hline \hline CLS-1 & 750 & 30 & 0.04 & 79 & 45 \\
\hline CLS-2 & 750 & 30 & 0.00 & 76 & 41.5 \\
\hline CLS-3 & 800 & 30 & 0.04 & 90.6 & 46.6 \\
\hline CLS-4 & 800 & 30 & 0.00 & 88.4 & 46.9 \\
\hline CLS-5 & 825 & 30 & 0.04 & 91.5 & 52.3 \\
\hline CLS-6 & 825 & 30 & 0.00 & 92 & 52.6 \\
\hline
\end{tabular}

The coal conversion values were calculated based on the assumption that all of the surfactant additive ends up in the THF-insoluble products. The results of these evaluation tests show that under the conditions employed, small amounts of the surfactant additive (sodium lignolsulfonate) do not have any significant effect on coal and resid conversion levels except at lower temperatures $\left(<750^{\circ} \mathrm{F}\right)$. 


\section{(ii) Solvent Quality Determination on Recycle Oils from Bench Run CMSL-2}

The solvent quality (aromatic or hydroaromatic character) for coal liquefaction, of the recycle oils (or pressure filter liquids) obtained from different Periods of the bench run CMSL-2, was determined by carrying out standard (modified Conoco tests) solvent quality determination on the pressure filter liquids from CMSL-2. The following conditions were employed:

$\begin{array}{ll}\text { Coal : } & \text { Illinois No. } 6,3.0 \mathrm{~g} \\ \text { Solvent : } & \text { PFLs from individual CMSL Periods, } 6.0 \mathrm{~g} \\ \text { Catalyst: } & \text { None } \\ \text { Temperature: } & 750^{\circ} \mathrm{F} \\ \text { Time: } & 30 \mathrm{~min} \\ \text { Pressure: } & 2000 \text { psig Nitrogen }\end{array}$

The results obtained, in terms of coal conversions in the microautoclave tests, are plotted in Figure 1. As shown in Figure 1, as the bench run progressed, the recycle solvent quality for coal liquefaction improved, indicating that solvent (PFL) became more and more aromatic/hydroaromatic as the run progressed.

\section{(iii) Laboratory Support for CMSL-3: Effect of Different Catalysts/Promoters on Water-Gas Shift Conversion}

\section{Background:}

Carbon monoxide and steam mixtures have been successfully employed instead of pure hydrogen in the gas phase for liquefaction of low rank coals. The equimolar mixture of $\mathrm{CO}$ and steam undergoes a shift reaction to produce $\mathrm{H}_{2}$ in situ. The water-gas shift reaction is known to be catalyzed by alkali like potassium. sodium, and even by metals like molybdenum added to the reaction mixture in suitable forms. The bench run 227-79 (CMSL-3) is planned to be carried out using syngas ( $\mathrm{CO}+\mathrm{H}_{2}$ ) with possibly different $\mathrm{CO} / \mathrm{H}_{2}$ ratios (with water injection in to feed slurries). It is therefore crucial to understand the effects of $\mathrm{CO} / \mathrm{H}_{2} \mathrm{O} / \mathrm{H}_{2}$ mixtures on conversion levels of Black Thunder mine coal.

(A) Microautoclave tests to evaluate the effectiveness of different WGS promoters/catalysts on Coal and Resid Conversions from Black Thunder Mine coal with a $50 / 50 \mathrm{CO} / \mathrm{H}_{2}$ mixture.

Ohjective: To determine the effect of different WGS promoters/catalysts on coal and resid conversions from Black Thunder Mine Wyoming coal with a synthesis gas $\left(50 / 50 \mathrm{v} / \mathrm{v}^{\circ} \%\right.$ $\mathrm{CO} / \mathrm{H}_{2} 2$ as feed gas. 
Reaction Conditions:

Coal:

Black Thunder Mine (HRI 5828 or L-780)

Solvent:

$\mathrm{CO}: \mathrm{H}_{2}$ Ratio:

HRI 6002 (Wilsonville Distillate)

Temperature:

$50 / 50$ by volume

Time:

$750^{\circ} \mathrm{F}$

Total Pressure: $\quad 1800$ psig

Total Water: $\quad 30 \mathrm{~W} \%$ of Dry Coal

Solvent/Coal Ratio: $4: 1$ 


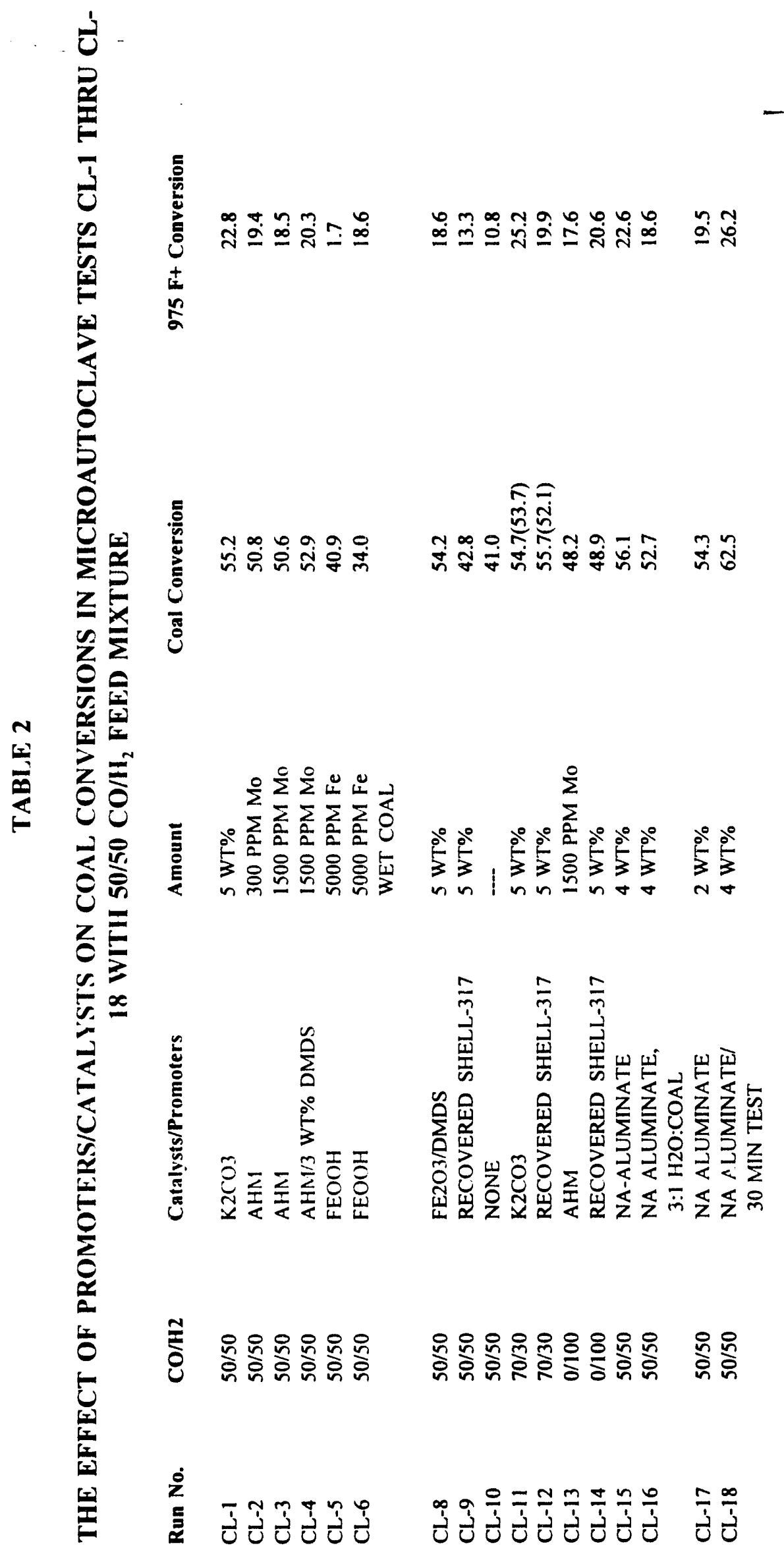


The apparent low values of total coal and residuum conversions (as shown in Table 2), obtained during the microautoclave tests CL-1 thru' CL-18, are mainly because of the short reaction time (15 minute) and $50 \%$ hydrogen in the gas phase (this functions to suppress the equilibrium of the Water-Gas Shift Reaction). Based on these results it can be said that potassium carbonate and ammonium heptamolybdate (with $3 \mathrm{~W} \%$ DMDS) gave almost comparable performance in terms of both coal and residuum conversions from Black Thunder Mine coal. The results obtained in the above tests warranted further testing in the microautoclave of different WGS promoters at higher reaction time (30 minutes) and with pure $\mathrm{CO}$ as a reducing gas in the gas phase with equimolar amount of water added (for WGS Reaction) to the feed mixture to the microautoclave.

(B) Microautoclave tests to evaluate the effectiveness of different WGS promoters/catalysts on Coal and Resid Conversions from Black Thunder Mine coal with pure $\mathrm{CO}$ as feed gas and longer reaction time.

Objective: To determine the effect of different WGS promoters/catalysts on coal and resid conversions from Black Thunder Mine Wyoming coal with a Pure $\mathrm{CO}$ as a feed gas/Equimolar Water added to the feed and longer reaction time.

11 more microautoclave tests were carried out in order to determine the effects of using pure $\mathrm{CO}$ in the gas phase and adding water to the reaction mixture at a concentration level that will give close to equimolar ratio of $\mathrm{CO}$ and steam in the gas phase under reaction conditions. The design pressure rating of the microautoclave system is $3300 \mathrm{psig}$ at $850^{\circ} \mathrm{F}$. Since the water added to the coal-solvent slurry is going to generate its own partial pressure under, action conditions, the amounts of $\mathrm{CO}$ and water (approximately an equimolar mixture) were estimated for a total system pressure of 2600 psig under reaction conditions. The starting pressure of $\mathrm{CO}$ is estimated close to $600 \mathrm{psig}$ (assuming it increases to about $1300 \mathrm{psig}$ at $750^{\circ} \mathrm{F}$, the reaction temperature. An equimolar amount of water is estimated to be $0.033 \mathrm{~g}$ moles which is about 30 percent by weight of the starting coal $(2.0 \mathrm{~g})$.

Typical Test Conditions:

$\begin{array}{ll}\text { Unit: } & \text { Microautoclave } \\ \text { Coal: } & \text { HRI-5828 and L-780, Black Thunder coal, } 2.0 \mathrm{~g} \\ \text { Solvent: } & \text { Recycle oil, } \mathrm{HRI}-6002,8.0 \mathrm{~g} \\ \text { Pressure: } & 2600 \mathrm{psig} \mathrm{CO}+\mathrm{H}_{2} \mathrm{O} \text { at reaction temperature } \\ \text { CO initial pressure: } & 800 \text { psig (cold) } \\ \text { Temperature: } & 750^{\circ} \mathrm{F} \\ \text { Reaction time: } & 30 \mathrm{~min} \\ \text { Water: } & 40 \mathrm{~W} \% \text { of dry coal. }\end{array}$


Table 3

Effect of Different Catalysts/Promoters on Coal Liquefaction under Water-Gas Shift Conditions with Pure $\mathrm{CO}$ as Feed Gas.

\begin{tabular}{|c|c|c|c|c||}
\hline Test No. & Catalyst & Wt\% Added $^{\text {at }}$ & \% Coal Conv. & $\begin{array}{c}\text { \% Resid } \\
\text { Conv. }\end{array}$ \\
\hline \hline $\mathrm{CL}-37$ & $\mathrm{~K}_{2} \mathrm{CO}_{3}$ & 5.0 & 76 & 43 \\
\hline $\mathrm{CL}-38$ & $\mathrm{AHM}$ & $1500 \mathrm{ppm}$ & 63 & 27 \\
\hline $\mathrm{CL}-39$ & $\mathrm{AHM}+\mathrm{DMDS}^{\mathrm{h}}$ & $1500 \mathrm{ppm}$ & 70 & 39 \\
\hline $\mathrm{CL}-40$ & $\mathrm{DMDS}$ & 3.0 & 69 & 33 \\
\hline $\mathrm{CL}-41^{\mathrm{d}}$ & $\mathrm{K}_{2} \mathrm{CO}_{3}$ & 5.0 & 72 & 42 \\
\hline $\mathrm{CL}-42^{\mathrm{d}}$ & $\mathrm{AHM}_{\mathrm{DMMDS}}$ & $1500 \mathrm{ppm}$ & 64 & 28 \\
\hline $\mathrm{CL}-43$ & $\mathrm{SHELL}-317$ & 100 & 75 & 41 \\
\hline $\mathrm{CL}-44$ & $\mathrm{NaAlO}_{2}$ & 4.0 & 77 & 38 \\
\hline $\mathrm{CL}-45^{\mathrm{c}}$ & $\mathrm{K}_{2} \mathrm{CO}_{3}$ & 5.0 & 75 & 38 \\
\hline $\mathrm{CL}-46$ & $\mathrm{~K}_{2} \mathrm{CO}_{3}$ & 5.0 & 70 & 29 \\
\hline $\mathrm{CL}-47$ & $\mathrm{NaAlO}_{2}$ & 4.0 & 78 & 34 \\
\hline
\end{tabular}

a relative to MAF coal added.

"he amount of DMDS added was $3 \mathrm{wt} \%$ relative to $\mathrm{mt}$ coal.

'this run was carried out for 60 minutes of re?tion time.

using untried L-780 coal.

As shown in Table 3, ammonium heptamolybdate (with DMDS) and potassium carbonate were found to result in the best coal and resid conversion values. Although, potassium carbonate, in both the reaction serics ( ( $1 .-1$ thru' 18 and $C L-37$ thru'47), has resulted ir: a shade better performance than ammonium heptamolybdate (AHM), a judicious choice was made to select AHM as an ultimate catalyst additive for the Bench Run for the following reasons:

(1) Ammonium heptamolybdate, when used at 1500 Mo relative to coal (with a proper sulfiding agent), has been proven to be an active slurry catalyst for the first stage of coal liquefaction.

(2) The use of any alkali-based promoter (such as $\mathrm{K}_{2} \mathrm{CO}_{3}$ or $\mathrm{NaAlO}_{2}$ ) for the WGS reaction was not desirable from the point of deactivation of the supported catalyst (acid site poisoning by the alkali in the promoter). Supported catalyst was planned for use in Bench Run CMSL-3. 
(3) As exemplified by the activity data (Figure 2), discussed in the next sub-section, AHM (with DMDS) was indeed found to be a good catalyst for the WGS reaction; these reactions were carried out in the absence of any coal (only $\mathrm{CO}$ and water were used for these tests).

\section{(iv) Evaluating the Effect of Different Catalysts/Promoters on Water-Gas Shift Conversion Levels in the Absence of Coal and with/without a Solvent:}

The microautoclave tests series CL-74 through CL-85 were carried out in order to compare the effectiveness of different catalysts/promoters for the Water-Gas Shift conversion only, i.e., these tests were carried out in the absence of any coal; the only reactants were carbon monoxide and water. The following were the common conditions employed for these tests; the product work-up included GC analysis of the product gases from such tests.

\section{Conditions:}

Solvent :

Water:

$\mathrm{CO}$ pressure (cold):

$\mathrm{T}: 750^{\circ} \mathrm{F}$ and $\mathrm{t}$ :

$\mathrm{CO} / \mathrm{H}_{2} \mathrm{O}$ molar ratio:
L-769, $8.0 \mathrm{~g}$ wherever used.

$0.85 \mathrm{~g}$

800 psig

$30 \mathrm{~min}$

$1: 1$

Table 4

\section{Effect of Different Catalysts/Promoters on Water-Gas Shift Conversion}

\begin{tabular}{|c|c|c|c|}
\hline Test No. & Solvent & Catalyst/Promoter & $\% \mathrm{CO}$ Conversion ${ }^{\prime}$ \\
\hline CL-74 & YES & $\mathrm{K} 2 \mathrm{CO} 3,5 \mathrm{~W} \%$ of $2.0 \mathrm{~g}$ & 14.02 \\
\hline CL-75 & no & $=$ same $=$ & 14.70 \\
\hline CL-76 & y'es & $\mathrm{NaAlO} 2,4 \mathrm{~W} \%$ of $2.0 \mathrm{~g}$ & 11.21 \\
\hline CL-77 & no & $\mathrm{NaAlO} 2,4 \mathrm{~W} \%$ of $2.0 \mathrm{~g}$ & 17.50 \\
\hline CL-78 & yes & $\mathrm{Fe} 2 \mathrm{O} 3,0.1 \mathrm{~g}$ & 3.91 \\
\hline $\mathrm{CL}-79$ & no & $\mathrm{Fe} 2 \mathrm{O} 3,0.1 \mathrm{~g}$ & 5.75 \\
\hline CL-80 & yes & AHM+DMDS ${ }^{2}$ & 20.2 \\
\hline $\mathrm{CL}-81$ & no & $\mathrm{AHM}+\mathrm{DMDS}$ & 27.9 \\
\hline CL-82 & yes & None & 8.20 \\
\hline CL- 83 & no & None & 12.7 \\
\hline CL-84 & yes & Amocat $1 \mathrm{~A}^{3}$ & 31.2 \\
\hline CL-85 & no & Amocat $1 \mathrm{~A}$ & 29.6 \\
\hline
\end{tabular}

$1 \% \mathrm{CO}$ conversion in the WGS reaction was calculated as $\% \mathrm{CO}_{2}$ in the products $/\left(\% \mathrm{CO}+\% \mathrm{CO}_{2}\right)$ in the products. This definition was used for CO-conversion by the WGS reaction because there was NO contribution to product $\mathrm{CO}_{2}$ from coal in these tests.

$2375 \mathrm{ppm}$ Mo (relative to $8.0 \mathrm{~g}$ of the solvent) was used as ammonium heptamolybdate with $3 \%$ DMDS.

${ }^{3}$ This is a $\mathrm{Co}-\mathrm{Mo} / \mathrm{Al}_{2} \mathrm{O}_{3}$ catalyst. 
Thus, the results obtained from these series of tests indicate that molybdenum-based water-soluble slurry catalyst and the supported Co-Mo/Alumina (Amocat $1 \mathrm{~A}$ ) catalyst are the most effective catalysts for the shift conversion. Since, the use of syngas is planned only in the first stage of the CMSL-3, a slurry catalyst was selected for the Bench run based on similar experiments in the literature'.

1 Amestica, L.A. and Wolf, E.E., "Catalytic liquefaction of coal with supercritical water/CO/solvent media" Fuel, 1986, Vol. 65, pp. 1226-1232. 
$\frac{-1}{2}$

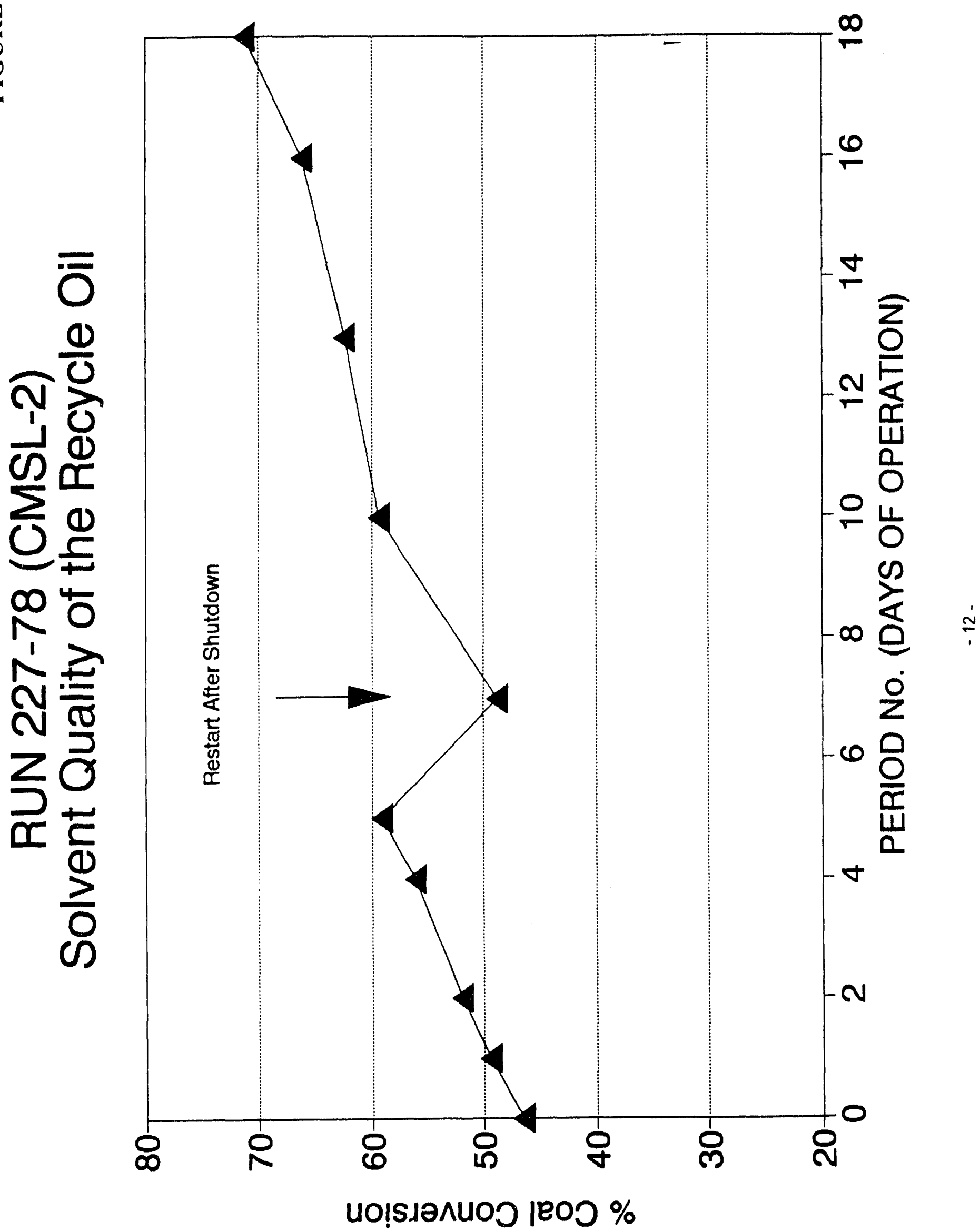




\section{TASK 3 - BENCH-SCALE STUDIES}

\section{RUN CMSL-2: Lower Solvent-to-Coal Ratio and Effect of Surfactant}

Bench Run CMSL-2, for the evaluation of the impact of low solvent-to-coal ratios on the liquefaction of a bituminous Illinois No.6 coal, was conducted during this reporting period in HRI's CTSL ${ }^{\mathrm{TM}}$ mode.

\section{Objectives}

The objective of the Bench Run CMSL-2 was to evaluate the impact of lower solvent-to-coal ratios (1.1-0.9) on the liquefaction of Illinois No. 6 coal under the CTSL catalytic/catalytic mode of operation. Solvent-to-coal ratio has a direct impact on the economics of CTSL. The lower this ratio, the higher is the amount of coal that can be processed at a fixed reactir volume. As coal and $975^{\circ} \mathrm{F}^{+}$residuum conversions are non-zero order reactions, higher coal concentrations in the feed slurries can enhance the reaction kinetics. Most of the previous coal liquefaction work at HRI was carried out at solvent-to-coal ratios of between 1.5-2.5. The lower limit on solvent/coal ratio depends on the pumpability of the feed slurries at the selected operating conditions. Also, from the viewpoint of chemistry of direct liquefaction, a critical amount of solvent in the liquefaction reactor is always necessary in order to provide adequate hydrogen for the stabilization of the reactive fragments generated from coal. The other objectives of this bench Run were to evaluate the effect of reaction severity at high coal loading conditions and to evaluate the effect of the addition of sodium lignolsulfonate ( $2 \mathrm{~W} \%$ of coal feed) on the conversions and liquid yield at a solvent-to-coal ratio of 0.9 .

\section{Operations and Results}

The bench Run CMSL-2, carried out to evaluate the impact of lower solvent-to-coal ratios on the CTSL performance, was successfully completed on May 6, 1993 after 17 and 2/3 days of operation. The overall Run CMSL-2 consisted of four different operating conditions; the first three conditions to evaluate the effect of solvent-to-coal ratios of 1.1 and 0.9 on the process performance at different reaction severities (higher coal space velocities and higher reactor temperatures for Conditions 3 and 4) where as the last Condition of CMSL-2 (Condition 4) was carried out as an extension for the subcontract with the Jet Propulsion Laboratory for the evaluation of a surfactant additive ( $2 \mathrm{~W} \%$ of sodium lignolsulfonate relative to coal feed) on the performance of bituminous coal liquefaction. Burning Star Mine 2 Illinois No. 6 coal was used for this run with L-769 as the start-up/make-up solvent and fresh Shell-317 catalyst (1/32" extrudates) which was sulfided using TNPS prior to Condition 1 of the run.

The coal for this run was an Illinois No. 6 coal (Burning Star Mine 2) dried to about $2 \mathrm{~W} \%$ moisture content (designated as HRI-6107). The catalyst was Shell-317 NiMo/ $\mathrm{Al}_{2} \mathrm{O}_{3} 1 / 32$ " extrudates for both stages. The start-up/make-up oil was L-769 (a blend of a topped distillate from Wilsonville and pressure filter liquid from the PDU 260-03 run made using Black Thunder Mine coal). The entire run was carried out at four different operating conditions designed to discretely evaluate the effect of increasing coal concentration in the feed slurry, the effect of reaction severities at high coal loadings, and the effect of a surfactant addition on the CTSL process performance. The feed flowrates (or space velocities) and stage temperatures were so chosen as to allow a direct comparison of CMSL-2 with the other bench runs on Illinois No. 6 using Shell-317 catalyst that were carried out at higher solvent-to-coal ratios (lower coal concentrations). 
The operating conditions (Run Plan) for CMSL-2 are given in Table 5. As shown in Table 5, CMSL-2 consisted of four Conditions each lasting for about 3-5 days. Condition 1 which was 5 days long was intended to bring the run to a steady state (to represent equilibrated results) at first and second stage reactor temperatures of 750 and $800^{\circ} \mathrm{F}$, respectively, the dry coal space velocity of $46 \mathrm{lbs} / \mathrm{hr} / \mathrm{ft}^{3}$ catalyst (per stage) and solvent-to-coal ratio of 1.1. The Condition 2, as per the original Run Plan, was planned to be 4 days long with a solvent-to-coal ratio of 0.8 (all other parameters same as Condition 1) had to be revised after a temporary shut-down at the beginning of that Condition due to excessive plugging problems. The revised Condition 2, as shown in Table 5, was four days long and used solvent-to-coal ratio of 0.9 with all other parameters same as Condition 1. In Condition 3, reaction severity was changed by increasing the reactor temperatures to 775 and $810^{\circ} \mathrm{F}$ for the first and the second stage, respectively. The dry coal space velocity was increased to $69 \mathrm{lbs} / \mathrm{hr} / \mathrm{ft}^{3}$ catalyst (per stage). The final Condition (Condition 4), 4 and $2 / 3$ days long, was an extension of this run for a sub-contract with the Jet Propulsion Laboratory (JPL) for the evaluation of the surfactant. Two weight percents of sodium lignolsulfonate was added continuously to the feed slurry; all other parameters were same as Condition 3. The last one and $1 / 3$ day in Condition 4, the reactor temperatures were lowered to 750 and $795^{\circ} \mathrm{F}$ for the first and the second stage, respectively as per the request of JPL.

The modified feed preparation and introduction system for CMSL-2 consisted of a slurry preparation and mixing tank (dry tank) that prepared coal-solvent slurries in twelve hour batches, mixed them uniformly, heated to temperatures high enough $\left(200-450^{\circ} \mathrm{F}\right)$ to maintain a pumpable slurry viscosity and transferred to the feed charge pot. Prior to the beginning of CMSL-2 an off-line slurry pumping test was conducted to evaluate the pumpability of coal-solvent slurries of different coal loadings using the newly installed hot slurry preparation and feed system. An average material recovery balance of $97.7 \mathrm{~W} \%$ was obtained for this bench run. This value is tad lower than what it normally is. This could be because of the fact that a more involved feed preparation system was used for this bench run that allowed preparation of thicker slurries (high coal concentrations) and transporting the same to the actual feed charge pot at high temperatures $\left(200-450^{\circ} \mathrm{F}\right)$ to maintain a proper pumpable viscosity. At the beginning of Condition 2 (as per the initial Run Plan) when solvent-to-coal ratio was about 0.8 , the unit had to be shut down due $t 0$, excessive plugging problems in the feed pump discharge lines. Except for this shutdown, the entire run operation went on smoothly without any major disturbances.

The analy'ses of results obtained from CMSL-2 shows that $\mathrm{C}_{1}-\mathrm{C}_{3}$ gas yields varied between 4.20 to 5.89 W\% of dry coal. Coal conversion values of 91.7 to $93.2 \mathrm{~W} \%$ maf coal were obtained with $975^{\circ} \mathrm{F}^{+}$resid conversions of between 73.4 to $91.2 \mathrm{~W} \%$ maf coal and $\mathrm{C}_{4}-975^{\circ} \mathrm{F}$ distillate yields of 63 to $76.6 \mathrm{~W} \%$ maf coal. HDS and HDN were also significant (between about 69 to $91 \mathrm{~W} \%$ ). The process performance dropped sharply in going from Period 16 to 18 because of the fall in reaction severity. The temperatures of both the reaction stages were dropped by 25 and $15^{\circ} \mathrm{F}$, respectively, for the last two Periods as per the request of the JPL. The results obtained during the Condition 4 of the bench Run CMSL-2 indicate that the addition of sodium lignolsulfonate surfactant did not improve or enhance the performance of the CTSL process either in terms of product yields or product quality. The results obtained during CMSL-2, in terms of conversions and normalized product yields are summarized in Table 6. The hydrocarbon gas yields, hydrogen consumptions, distillate yields \& selectivity, and heteroatom removal results are plotted in Figures 3 through 8. 


\section{Effect of the Added Surfactant on Liquefaction}

The last condition of this run (Condition 4) was carried out as an extension for the sub-contract with the Jet Propulsion Laboratory for the evaluation of a surfactant additive on process performance. This condition lasted for 4 and $2 / 3$ days (run periods 14 thru 18B) with first three and $1 / 3$ days of operation at high stage temperatures (first stage $=775^{\circ} \mathrm{F}$ and second stage $=810^{\circ} \mathrm{F}$ ) and one and $1 / 3$ day at lowered stage temperatures (first stage $=750^{\circ} \mathrm{F}$ and second stage $=795^{\circ} \mathrm{F}$ ). Two weight percents (relative to coal) of sodium lignolsulfonate, a surfactant developed by the JPL, were added to the feed slurry as -70 mesh powder. The addition of this surfactant did not seem to improve process performance to any distinguishable extent. Coal conversions of the order of $92-93 \%$ (maf coal) were obtained with $\mathrm{C}_{4}{ }^{-}$ $975^{\circ} \mathrm{F}$ distillate yields in the range of $63-69 \mathrm{~W} \%$ (maf coal) and $975^{\circ} \mathrm{F}^{+}$resid conversions of $73-84 \mathrm{~W} \%$ (maf coal). These values were either almost as good or worse (period $18 \mathrm{~A} / \mathrm{B}$ ) than the values of yields and conversions obtained at the equivalent catalyst age and same reaction conditions for other bench runs for Illinois No. 6 coal carried out previously by HRI. in CTSL mode, without addition of any surfactant. Our results from this bench run utilizing the surfactant in the last 4 and $2 / 3$ days of operation do not indicate any enhancing effect of the surfactant on the process performance. The properties of the recycle solvent (pressure filter liquid) from CMSL-2, obtained both, in the presence and the absence of the surfactant additive are shown in Figure 9. The variation in the properties of the recycle oil does not indicate any effect of the additive on coal liquefaction process.

\section{Effect of Lower Solvent-to-Coal Ratios: Comparison between Bench Runs}

The performance of the Bench Run CMSL-2 is compared with that of the Run I-18 in Table 7, 8 and Figurc 10. Tuble 7 which compares the process performance at lower reaction temperatures (during some of the earlier run-periods), indicates definitely a superior process performance for CMSL-2 (with solicm-to-coal ratio between 0.9-1.06) than I-18 (solvent-to-coal ratio of about 1.6) not only in terms of higher $975^{\circ} \mathrm{F} \cdot$ residuum conversion (4-6 W\% maf coal) but also in terms of higher $\mathrm{C}_{4}-975^{\circ} \mathrm{F}$ distillate yiclds (hy 3-7 $\mathrm{W}^{\circ} \%$ maf coal). Figure 10 compares the $\mathrm{C}_{4}-975^{\circ} \mathrm{F}$ distillate selectivity for CMSL-2 and $1-18$ for selected run-periods. The selectivity to light naphtha and middle distillates for both the Periods during CMSL-2, shown in Figure 10, is higher than that for corresponding Periods during 1-18.

Another Bench Run, CC-16, which was liquefaction of Illinois No. 6 coal in CTSL mode carried out for the evaluation of an Akzo AO-60 catalyst, was used for comparison of process performance (under similar reaction conditions) with CMSL-2. Since it had already been shown that Akzo AO-60 catalyst resulted in as good a process performance as Shell-317 catalyst (used in CMSL-2), the comparison with C ( -16 was fair. As shown in Table 9 and 10, CMSL-2 results in a much better overall process performance with about $7-9 \mathrm{~W} \%$ (maf coal) higher $\mathrm{C}_{4}-975^{\circ} \mathrm{F}$ distillate yields. Also, as shown in Figure 11, the run-periods chosen for comparison from CMSL-2, resulted in a better product slate as far as the distillate selectivity is concerned, than the corresponding Periods during Run CC-16.

As mentioned earlier, the properties of the recycle oil (pressure filter liquid) are a good measure of the overall product quality from the CTSL bench runs. Table 11 compares the recycle oil properties for Bench Runs 1-18, CC-16, and CMSL-2 for Period 9. CMSL-2 has resulted in a better quality recycle oil, in terms of gravity, $\mathrm{H} / \mathrm{C}$ ratio, and heteroatom content, than either CC-16 or I-18. The amount of LGO and VGO fractions together, is higher for CMSL-2 recycle oil than the two other bench Runs. The amount of heavy $975^{\circ} \mathrm{F}^{\prime}$ residuum is lower for CMSL-2 recycle oil. Analyses of the individual PFL fractions also shows better properties for the recycle oil from CMSL-2. As shown in Figure 12, the 
$975^{\circ} \mathrm{F}^{+}$residuum content and even the amount of cyclohexane insolubles (asphaltene plus preasphaltene content) was much lower for the recycle oil from CMSL-2 than the same from the other two bench runs. Thus, CMSL-2, which employed lower solvent-to-coal ratios, resulted in a better overall product quality than either CC-16 or I-18. 


\section{SUMMARY}

The Bench Run CMSL-2, which was direct liquefaction of a bituminous Illinois No. 6 coal performed in the CTSL mode, indicated an improved CTSL process performance at higher coal loadings (47-53 W $\%$ of the feed slurry). Both the product yields and quality were influenced positively as an effect of processing slurries with high coal concentrations. The overall Run operations also went on smoothly at these low solvent-to-coal ratios (0.9-1.1). Sodium lignolsulfonate, a surfactant additive developed by the Jet Propulsion Laboratory, did not have any effect either on the conversion levels or the product yields and quality under the conditions of the Bench Run CMSL-2. 


\section{Table 5}

\section{Run Plan for CMSL-2}

\begin{tabular}{|c|c|c|c|c|c|}
\hline $\begin{array}{l}\text { Condition } \\
\text { Periods }\end{array}$ & $\begin{array}{l}1 \\
1-5\end{array}$ & $\begin{array}{l}2^{\circ} \\
6-10\end{array}$ & $\begin{array}{l}3 \\
11-13\end{array}$ & \multicolumn{2}{|c|}{$14-17 A$ 17B-18B } \\
\hline \multicolumn{6}{|l|}{ Temperature, ${ }^{\circ} \mathrm{F}$} \\
\hline First stage reactor & 750 & 750 & 775 & 775 & 750 \\
\hline Second stage reactor & 800 & 800 & 810 & 810 & 795 \\
\hline Hot separator & 600 & 600 & 600 & 600 & 600 \\
\hline Atmospheric still & 625 & 620 & 620 & 620 & 620 \\
\hline Solvent/Coal ratio & 1.1 & 0.9 & 0.9 & 0.9 & 0.9 \\
\hline $\begin{array}{l}\text { Space velocity, } \\
\text { Ib dry coal/hr/ } / \mathrm{ft}^{3} \text { cat } \\
\text { (per stage) }\end{array}$ & 46 & 46 & 69 & 69 & 69 \\
\hline Additive $\ddot{*}$ W\% coal feed & 0 & 0 & 0 & 2 & 2 \\
\hline \multicolumn{6}{|l|}{ Recycles (W\% dry coal) } \\
\hline PFL to slurry & 110 & 90 & 90 & 90 & 90 \\
\hline Buffer first stage & 4.0 & 4.0 & 4.0 & 4.0 & 4.0 \\
\hline Buffer second stage & 4.0 & 4.0 & 4.0 & 4.0 & 4.0 \\
\hline
\end{tabular}

- Each Period (day) is subdivided into three sub-periods, $A, B$, and $C$. The Run was suspended in Period $6 A$ due to operability problems and was restarted in Period $7 B$.

“. Sodium lignolsulfonate, a surfactant supplied by Jet Propulsion Laboratory, was the additive. 
Table 6

Operations Summary and Process Performance for CMSL-2

COAL : ILLINOIS NO. 6 HRI-6107

CATALYST : SHELL-317 HRI-5394 (BOTH STAGES)

Period Number

$\begin{array}{lllll}4 & 10 & 13 & 16 & 18\end{array}$

Date (Start of Period)

$\begin{array}{lllll}04 / 18 & 04 / 28 & 05 / 01 & 05 / 04 & 05 / 06 / 93\end{array}$

Hours of Run (End of Period)

96. 232. 304. 376. 416.

Stage 2 Catalyst Age,Lb Dry Coal/Lb Cat. 124. 295. 422. 534. 597.

1st Stage Temperature ('F)

752. 751. 777. 776. 752 .

2nd Stage Temperature ('F)

801. 802. 812. 811. 796.

Unit Back Pressure (PSIG)

2492. 2503. 2500. 2502. 2500 .

Space Velocity, $\mathrm{Lb} \mathrm{Coal} / \mathrm{Hr} / \mathrm{Ft}^{3}$ Catalyst $\quad 41.1 \quad 41.0 \quad 74.2 \quad 62.3 \quad 63.6$

\section{W\% OF DRY COAL}

PFL Recycle

PFL to Buffer to Stage 1

PFL to Buffer to Stage 2

Make-up Oil

$\begin{array}{lllll}93.9 & 90.1 & 90.2 & 90.3 & 88.6\end{array}$

$\begin{array}{lllll}4.4 & 4.5 & 2.6 & 3.1 & 2.4\end{array}$

$\begin{array}{lllll}4.6 & 4.4 & 2.6 & 3.6 & 2.8\end{array}$

$\begin{array}{lllll}12.9 & 0.0 & 0.0 & 0.0 & 0.0\end{array}$

$\begin{array}{llllll}\text { SOLVENT-TO-COAL (DRY) RATIO } & 1.06 & 0.9 & 0.9 & 0.9 & 0.9\end{array}$

MATERIAL BALANCE (\%) (GROSS) $\quad 101.64 \quad 99.25 \quad 97.28 \quad 97.69 \quad 92.96$

\section{ESTIMATED NORMALIZED YIELDS, W\% DRY FRESH FEED}

$\begin{array}{llllll}\mathrm{C}_{1}-\mathrm{C}_{3} \text { in Gases } & 4.45 & 5.22 & 4.73 & 5.21 & 4.32 \\ \mathrm{C}_{4}-\mathrm{C}_{7} \text { in Gases } & 3.11 & 3.80 & 3.36 & 3.25 & 3.26 \\ \mathrm{IBP}-390^{\circ} \mathrm{F} \text { in Liquids } & 17.48 & 15.89 & 14.75 & 11.12 & 8.32 \\ 390-500^{\circ} \mathrm{F} \text { in Liquids } & 13.01 & 11.13 & 8.09 & 8.78 & 7.34 \\ 500-650^{\circ} \mathrm{F} \text { in Liquids } & 27.59 & 27.52 & 20.52 & 20.01 & 15.76 \\ 650-850^{\circ} \mathrm{F} \text { in Liquids } & 5.69 & 7.36 & 12.34 & 14.37 & 18.16 \\ 850-975^{\circ} \mathrm{F} \text { in Liquids } & 0.63 & 1.04 & 3.36 & 3.73 & 6.02 \\ \text { Toluene Soluble } 975^{\circ} \mathrm{F}^{+} \text {Oil } & 1.34 & 1.95 & 5.66 & 8.15 & 15.58 \\ \text { Toluene Insoluble } 975^{\circ} \mathrm{F}^{+} \mathrm{Oil} & 0.01 & 0.02 & 0.12 & 0.17 & 0.32 \\ \text { Unconverted Coal } & 6.27 & 6.28 & 6.69 & 5.98 & 7.28 \\ \text { Ash } & 12.04 & 12.04 & 12.04 & 12.04 & 12.04 \\ \mathrm{~W}^{\prime} \text { ater } & 10.77 & 10.18 & 10.14 & 8.66 & 2.33 \\ \mathrm{CO} & 0.07 & 0.10 & 0.15 & 0.16 & 0.20 \\ \mathrm{CO} & 0.04 & 0.04 & 0.12 & 0.15 & 0.29 \\ \mathrm{NH}_{3} & 1.40 & 1.40 & 1.31 & 1.23 & 1.00 \\ \mathrm{H}_{2} \mathrm{~S} & 3.37 & 3.40 & 3.29 & 3.21 & 3.03 \\ \mathrm{Total}\left(100+\mathrm{H}_{2} \text { Reacted }\right) & 107.28 & 107.37 & 106.67 & 106.21 & 105.24\end{array}$

\section{PROCESS PERFORMANCE}

$\begin{array}{llllll}\mathrm{C}_{4}-975^{\circ} \mathrm{F} \text { Distillates, W\% of MAF Coal } & 76.8 & 75.9 & 71.0 & 69.6 & 66.9\end{array}$

$\begin{array}{lllllll}975^{\circ} \mathrm{F}^{+} \text {Conversion, W\% MAF } & 91.3 & 90.6 & 85.8 & 83.7 & 73.6\end{array}$

$\begin{array}{llllll}\text { Coal Conversion, W\% MAF } & 92.9 & 92.9 & 92.4 & 93.2 & 91.7\end{array}$

$\begin{array}{llllll}\text { HDS, W\% } & 79.2 & 80.1 & 77.5 & \mathbf{7 5 . 6} & \mathbf{7 1 . 4}\end{array}$

$\begin{array}{llllll}\text { HDN, W\% } & 93.5 & 91.7 & 85.8 & 80.1 & 65.6\end{array}$ 
Table 7

Comparison of Process Performance for Period No. 4

During Two Bench CTSL Runs Using Same Catalyst

(Shell-317 1/32" Extrudates)

but Different Solvent-to-Coal Ratios.

\begin{tabular}{|c|c|c|c|c|c|c|}
\hline & \multicolumn{3}{|c|}{ Run I-18 } & \multicolumn{3}{|c|}{ Run CMSL-2 } \\
\hline SOLVENT-TO-COAL RATIO & \multicolumn{3}{|c|}{1.59} & \multicolumn{3}{|c|}{1.06} \\
\hline Catalyst Age (Lb Coal/Lb Cat) & \multicolumn{3}{|c|}{117} & \multicolumn{3}{|c|}{124} \\
\hline \multirow[t]{2}{*}{ REACTION CONDITIONS } & $\mathrm{T}: \mathrm{RX1}$ & $\mathrm{T}: \mathrm{RX} 2$ & SV & $\mathrm{T}: \mathrm{RX} 1$ & $\mathrm{~T}: \mathrm{RX} 2$ & SV \\
\hline & 750 & 800 & 46.7 & 752 & 801 & 41.1 \\
\hline Coal Conversion (W\% maf) & \multicolumn{3}{|c|}{93.4} & \multicolumn{3}{|c|}{92.9} \\
\hline $975^{\circ} \mathrm{F}+$ Conversion (W\% maf) & \multicolumn{3}{|c|}{87.6} & \multicolumn{3}{|c|}{91.3} \\
\hline $\mathrm{H}_{2}$ Consumption (W \% dry) & \multicolumn{3}{|c|}{6.58} & \multicolumn{3}{|c|}{7.28} \\
\hline \multicolumn{7}{|c|}{ YIELDS (W\% DRY BASIS) } \\
\hline $\mathrm{C}_{1}-\mathrm{C}_{3}$ Gases & \multicolumn{3}{|c|}{5.03} & \multicolumn{3}{|c|}{4.45} \\
\hline $\mathrm{C} 4-390^{\circ} \mathrm{F}$ & \multicolumn{3}{|c|}{15.94} & \multicolumn{3}{|c|}{20.59} \\
\hline $390-650^{\circ} \mathrm{F}$ & \multicolumn{3}{|c|}{33.16} & \multicolumn{3}{|c|}{40.60} \\
\hline $650-975^{\circ} \mathrm{F}$ & \multicolumn{3}{|c|}{16.65} & \multicolumn{3}{|c|}{6.32} \\
\hline $975^{\circ} \mathrm{F}+$ & \multicolumn{3}{|c|}{5.17} & \multicolumn{3}{|c|}{1.35} \\
\hline $\begin{array}{c}\mathrm{C}_{4}-975^{\circ} \mathrm{F} \text { Distillate Yield } \\
\text { (W\% maf Coal) }\end{array}$ & \multicolumn{3}{|c|}{73.6} & \multicolumn{3}{|c|}{76.8} \\
\hline
\end{tabular}


Table 8

Comparison of Process Performance Between Two Bench CTSL Runs Using Same Catalyst (Shell-317 1/32" Extrudates but Different Solvent-to-Coal Ratios.

\begin{tabular}{|c|c|c|c|c|c|c|}
\hline & \multicolumn{3}{|c|}{ Run 227-37-Period 09} & \multicolumn{3}{|c|}{ Run 227-78-Period 10} \\
\hline SOLVENT-TO-COAL RATIO & \multicolumn{3}{|c|}{1.59} & \multicolumn{3}{|c|}{0.90} \\
\hline Catalyst Age (Lb Coal/Lb Cat) & \multicolumn{3}{|c|}{264} & \multicolumn{3}{|c|}{295} \\
\hline \multirow[t]{2}{*}{ REACTION CONDITIONS } & $\mathrm{T}: \mathrm{RX} 1$ & $\mathrm{~T}: \mathrm{RX} 2$ & SV & $\mathrm{T}: \mathrm{RX} 1$ & $\mathrm{~T}: \mathrm{RX} 2$ & SV \\
\hline & 750 & 799 & 45.8 & 751 & 802 & 41.0 \\
\hline Coal Conversion (W\% maf) & \multicolumn{3}{|c|}{93.7} & \multicolumn{3}{|c|}{92.9} \\
\hline $975^{\circ} \mathrm{F}+$ Conversion (W\% maf) & \multicolumn{3}{|c|}{84.4} & \multicolumn{3}{|c|}{90.6} \\
\hline $\mathrm{H}_{2}$ Consumption (W\% dry) & \multicolumn{3}{|c|}{6.26} & \multicolumn{3}{|c|}{7.37} \\
\hline \multicolumn{7}{|c|}{ YIELDS (W\% DRY BASIS) } \\
\hline $\mathrm{C}_{1}-\mathrm{C}_{3}$ Gases & \multicolumn{3}{|c|}{5.15} & \multicolumn{3}{|c|}{5.22} \\
\hline $\mathrm{C} 4-390^{\circ} \mathrm{F}$ & \multicolumn{3}{|c|}{15.17} & \multicolumn{3}{|c|}{19.69} \\
\hline $390-650^{\circ} \mathrm{F}$ & \multicolumn{3}{|c|}{28.06} & \multicolumn{3}{|c|}{38.65} \\
\hline $650-975 " \mathrm{~F}$ & \multicolumn{3}{|c|}{18.26} & \multicolumn{3}{|c|}{8.40} \\
\hline $975^{\circ} \mathrm{F}+$ & \multicolumn{3}{|c|}{8.36} & \multicolumn{3}{|c|}{1.97} \\
\hline $\begin{array}{c}\mathrm{C}_{4}-975 \text { "F Distillate Yield } \\
\text { (W\% maf Coal) }\end{array}$ & \multicolumn{3}{|c|}{68.8} & \multicolumn{3}{|c|}{75.9} \\
\hline
\end{tabular}


Table 9

Comparison of Two CTSL Bench Runs: 227-76 (CC-16) with Akzo AO-60 Catalyst and 227-78 (CMSL-2) with Shell-317 Catalyst to Demonstrate the Effect of Solvent-to-Coal Ratios on Process Performance

\begin{tabular}{|c|c|c|c|c|c|c|}
\hline & \multicolumn{3}{|c|}{ Run CC-16-Period 07} & \multicolumn{3}{|c|}{ Run CMSL-2-Period 04} \\
\hline SOLVENT-TO-COAL RATIO & \multicolumn{3}{|c|}{1.5} & \multicolumn{3}{|c|}{1.1} \\
\hline Catalyst Age (Lb Coal/Lb Cat) & \multicolumn{3}{|c|}{133} & \multicolumn{3}{|c|}{124} \\
\hline \multirow[t]{2}{*}{ REACTION CONDITIONS } & $\mathrm{T}: \mathrm{RX1}$ & $\mathrm{T}: \mathrm{RX} 2$ & SV & $\mathrm{T}: \mathrm{RX1}$ & $\mathrm{T}: \mathrm{RX} 2$ & SV \\
\hline & 750 & 799 & 46.0 & 752 & 801 & 41.1 \\
\hline Coal Conversion (W\% maf) & \multicolumn{3}{|c|}{91.3} & \multicolumn{3}{|c|}{92.9} \\
\hline $975^{\circ} \mathrm{F}+$ Conversion (W\% maf) & \multicolumn{3}{|c|}{82.9} & \multicolumn{3}{|c|}{91.3} \\
\hline $\mathrm{H}_{2}$ Consumption (W\% dry) & \multicolumn{3}{|c|}{6.37} & \multicolumn{3}{|c|}{7.28} \\
\hline \multicolumn{7}{|c|}{ YIELDS (W\% DRY BASIS) } \\
\hline $\mathrm{C}_{1}-\mathrm{C}_{3}$ Gases & \multicolumn{3}{|c|}{5.29} & \multicolumn{3}{|c|}{4.45} \\
\hline $\mathrm{C} 4-390^{\circ} \mathrm{F}$ & \multicolumn{3}{|c|}{16.29} & \multicolumn{3}{|c|}{20.59} \\
\hline $390-650^{\circ} \mathrm{F}$ & \multicolumn{3}{|c|}{26.88} & \multicolumn{3}{|c|}{40.60} \\
\hline $650-975^{\circ} \mathrm{F}$ & \multicolumn{3}{|c|}{17.39} & \multicolumn{3}{|c|}{6.32} \\
\hline $975^{\circ} \mathrm{F}+$ & \multicolumn{3}{|c|}{7.48} & \multicolumn{3}{|c|}{1.35} \\
\hline $\begin{array}{c}\mathrm{C}_{4}-975^{\circ} \mathrm{F} \text { Distillate Yield } \\
\text { (W\% maf Cral) }\end{array}$ & \multicolumn{3}{|c|}{67.8} & \multicolumn{3}{|c|}{76.8} \\
\hline \multicolumn{7}{|c|}{ Heteroatom Removal } \\
\hline HDS, W\% & \multicolumn{3}{|c|}{76.8} & \multicolumn{3}{|c|}{79.2} \\
\hline HDN, W\% & \multicolumn{3}{|c|}{83.0} & \multicolumn{3}{|c|}{93.5} \\
\hline
\end{tabular}


Table 10

Comparison of Two CTSL Bench Runs: 227-76 (CC-16) with Akzo A0-60 Catalyst and 227-78 (CMSL-2) with Shell-317 Catalyst to Demonstrate the Effect of Solvent-to-Coal Ratios on Process Performance.

\begin{tabular}{|c|c|c|c|c|c|c|}
\hline & \multicolumn{3}{|c|}{ Run 227-76-Period 09} & \multicolumn{3}{|c|}{ Run 227-78-Period 10} \\
\hline SOLVENT-TO-COAL RATIO & \multicolumn{3}{|c|}{1.5} & \multicolumn{3}{|c|}{0.9} \\
\hline Catalyst Age (Lb Coal/Lb Cat) & \multicolumn{3}{|c|}{174} & \multicolumn{3}{|c|}{295} \\
\hline \multirow[t]{2}{*}{ REACTION CONDITIONS } & $\mathrm{T}: \mathrm{RX} 1$ & $\mathrm{~T}: \mathrm{RX2}$ & SV & $\mathrm{T}: \mathrm{RX} 1$ & $\mathrm{~T}: \mathrm{RX2}$ & SV \\
\hline & 752 & 800 & 46.4 & 751 & 802 & 41.0 \\
\hline Coal Conversion (W\% maf) & \multicolumn{3}{|c|}{92.5} & \multicolumn{3}{|c|}{92.9} \\
\hline $975^{\circ} \mathrm{F}+$ Conversion (W\% maf) & \multicolumn{3}{|c|}{84.4} & \multicolumn{3}{|c|}{90.6} \\
\hline $\mathrm{H}_{2}$ Consumption (W\% dry) & \multicolumn{3}{|c|}{6.46} & \multicolumn{3}{|c|}{7.37} \\
\hline \multicolumn{7}{|c|}{ YIELDS (W\% DRY BASIS) } \\
\hline $\mathrm{C}_{1}-\mathrm{C}_{3}$ Gases & \multicolumn{3}{|c|}{5.76} & \multicolumn{3}{|c|}{5.22} \\
\hline $\mathrm{C} 4-390^{\circ} \mathrm{F}$ & \multicolumn{3}{|c|}{17.18} & \multicolumn{3}{|c|}{19.69} \\
\hline $390-650^{\circ} \mathrm{F}$ & \multicolumn{3}{|c|}{28.03} & \multicolumn{3}{|c|}{38.65} \\
\hline $650-975^{\circ} \mathrm{F}$ & \multicolumn{3}{|c|}{16.13} & \multicolumn{3}{|c|}{8.40} \\
\hline $975^{\circ} \mathrm{F}+$ & \multicolumn{3}{|c|}{7.28} & \multicolumn{3}{|c|}{1.97} \\
\hline $\begin{array}{c}\mathrm{C}_{4}-975^{\circ} \mathrm{F} \text { Distillate Yield } \\
(\mathrm{W} \% \text { maf Coal }) \\
\end{array}$ & \multicolumn{3}{|c|}{68.6} & \multicolumn{3}{|c|}{75.9} \\
\hline \multicolumn{7}{|c|}{ Heteroatom Removal } \\
\hline HDS, W\% & \multicolumn{3}{|c|}{76.0} & \multicolumn{3}{|c|}{80.1} \\
\hline $\mathrm{HDN}, \mathrm{W} \%$ & \multicolumn{3}{|c|}{83.3} & \multicolumn{3}{|c|}{91.7} \\
\hline
\end{tabular}


Table 11

Comparison of Recycle Oil Properties

for Three Bench Runs, I-18, CC-16, and CMSL-2

Run (Period) I-18 (9) CC-16 (9) CMSL-2 (10)

\begin{tabular}{|c|c|c|c|}
\hline Catalyst & Shell-317 & Akzo AO-60 & Shell-317 \\
\hline Age (lb coal/lb cat) & 264 & 174 & 295 \\
\hline Solvent/Coal Ratio & 1.6 & 15 & 09 \\
\hline \multicolumn{4}{|l|}{ PFL Properties } \\
\hline${ }^{\circ}$ API Gravity & 3.7 & 4.9 & 11.2 \\
\hline $\mathrm{H} / \mathrm{C}$ Ratio & 1.24 & 1.25 & 1.39 \\
\hline Nitrogen, W\% & 0.34 & 0.30 & 0.22 \\
\hline Sulfur, W\% & 0.05 & 0.07 & 0.06 \\
\hline \multicolumn{4}{|l|}{ Weight Percent } \\
\hline IBP- $650^{\circ} \mathrm{F}$ & 9.5 & 10.1 & 11.3 \\
\hline $650-850^{\circ} \mathrm{F}$ & 43.9 & 45.7 & 55.5 \\
\hline $850-975^{\circ} \mathrm{F}$ & 16.1 & 14.8 & 11.2 \\
\hline $975^{\circ} \mathrm{F}^{+}$ & 30.5 & 28.8 & 21.2 \\
\hline \multicolumn{4}{|l|}{ 650-850'F Fraction } \\
\hline H/C Ratio & 1.40 & 1.37 & 1.49 \\
\hline Nitrogen, W\% & 0.09 & 0.13 & 0.05 \\
\hline \multicolumn{4}{|l|}{ 850-975 ${ }^{\circ} \mathrm{F}$ Fraction } \\
\hline$\overline{\mathrm{H} / \mathrm{C} \text { Ratio }}$ & 1.20 & 1.19 & 1.27 \\
\hline Nitrogen, W\% & 0.27 & 0.29 & 0.21 \\
\hline \multicolumn{4}{|l|}{$975^{\circ} \mathrm{F}+$ Fraction } \\
\hline H/C Ratio & 1.03 & 0.98 & 1.03 \\
\hline Nitrogen, W\% & 0.81 & 0.68 & 0.52 \\
\hline Sulfur, W\% & 0.25 & 0.16 & 0.09 \\
\hline Cyclohexane Insol, W\% & 23.3 & 24.2 & 5.8 \\
\hline Toluene Insolubles, W\% & 2.2 & 1.8 & 0.7 \\
\hline
\end{tabular}




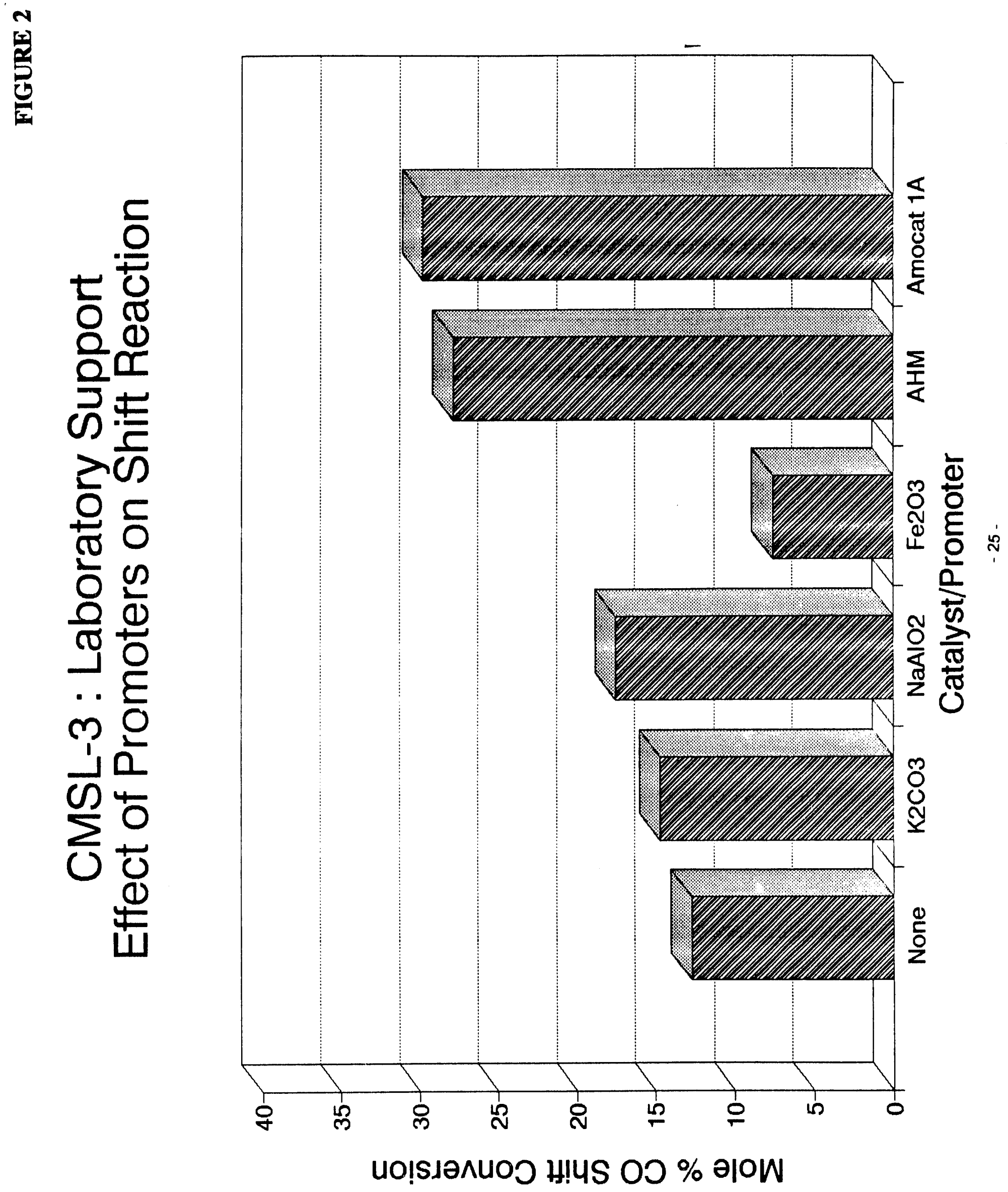


$\sum_{0}^{\infty}$
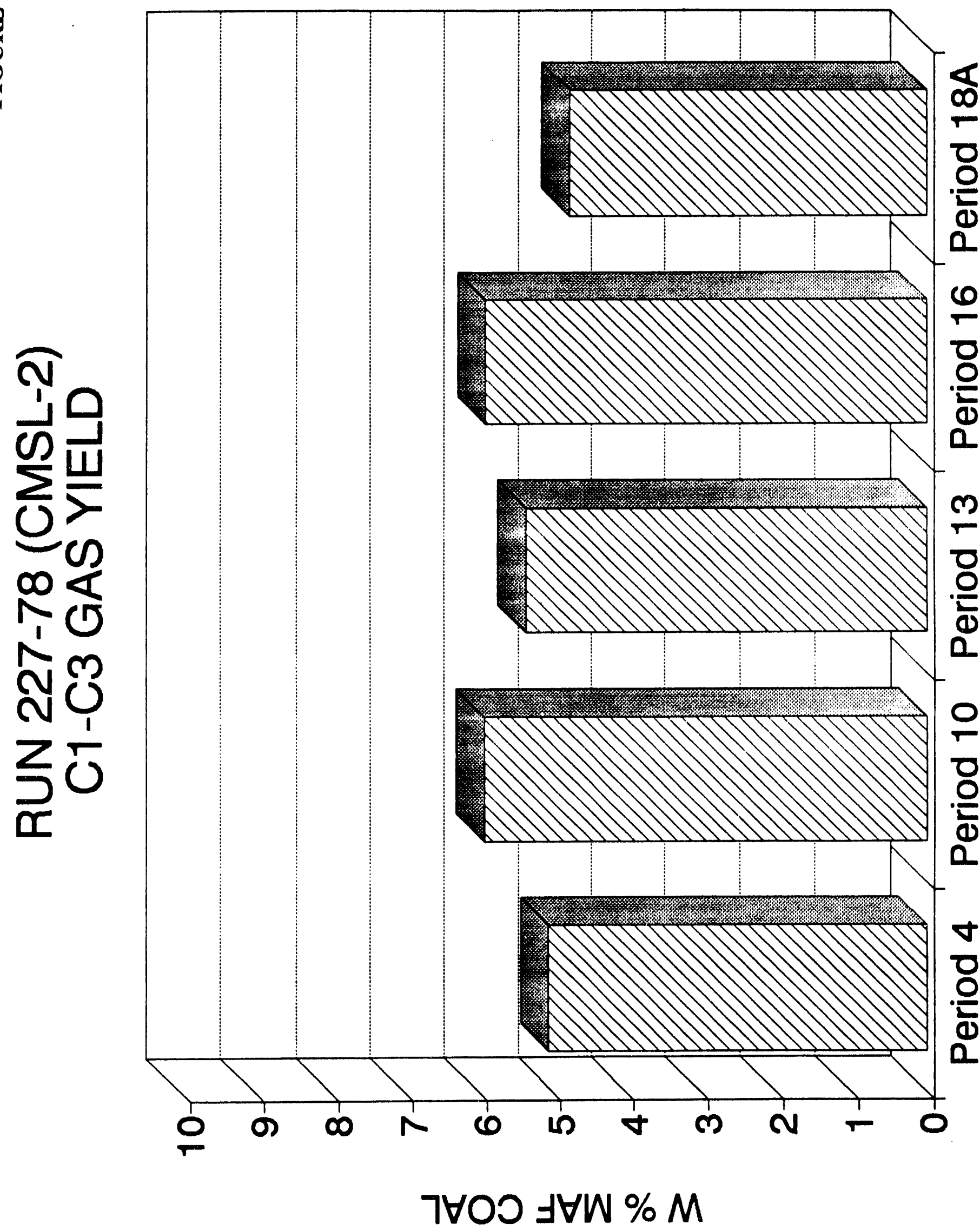


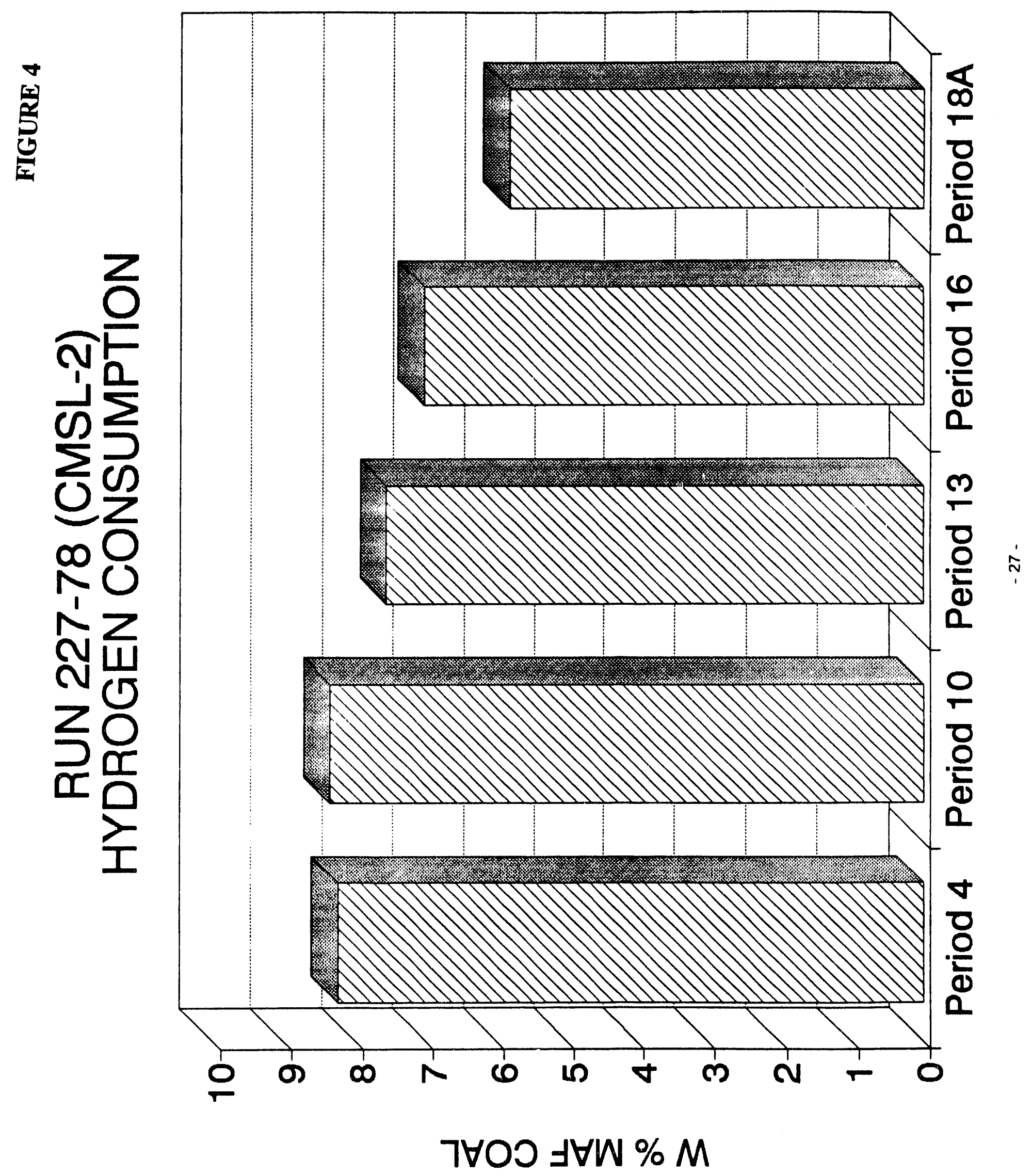




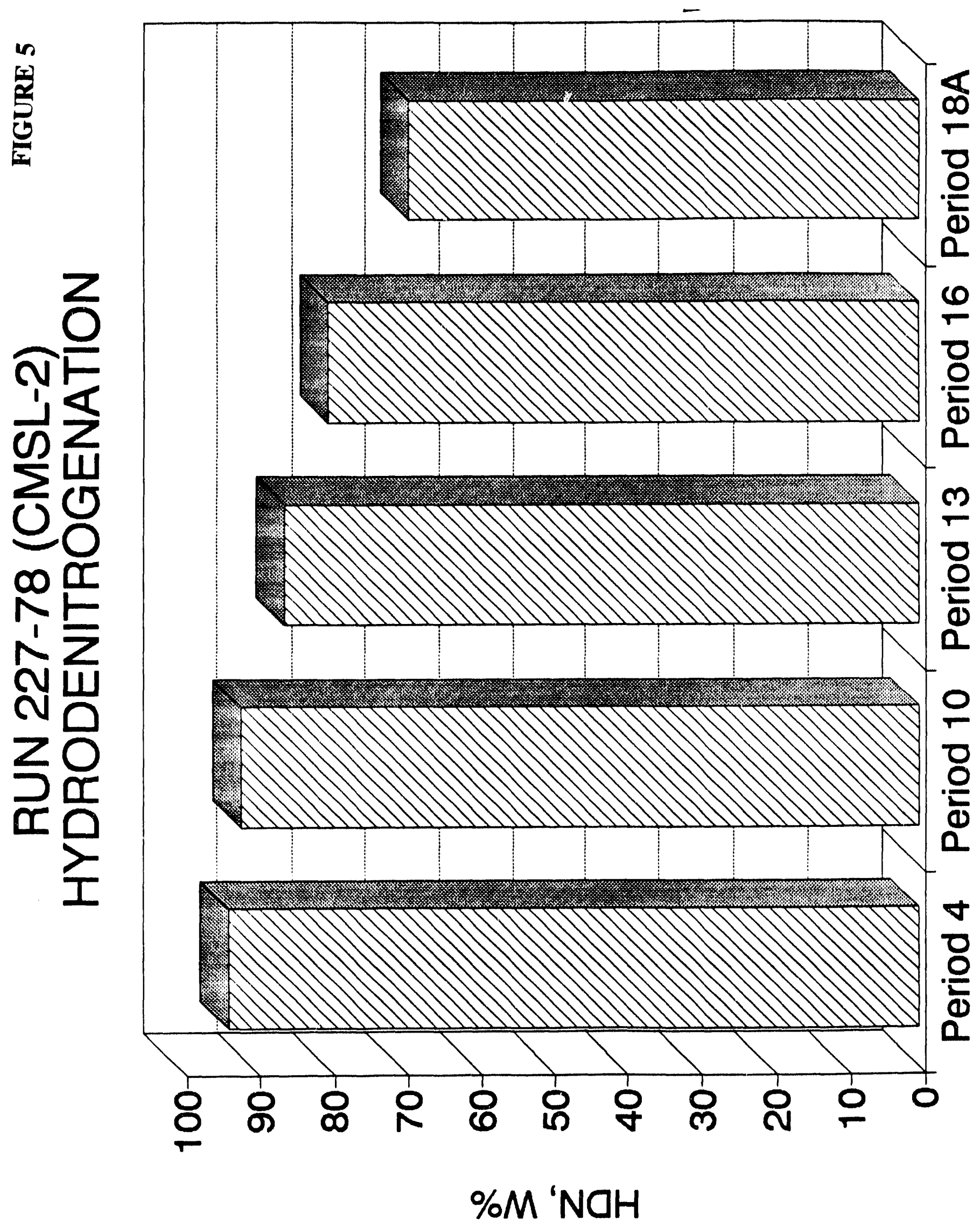




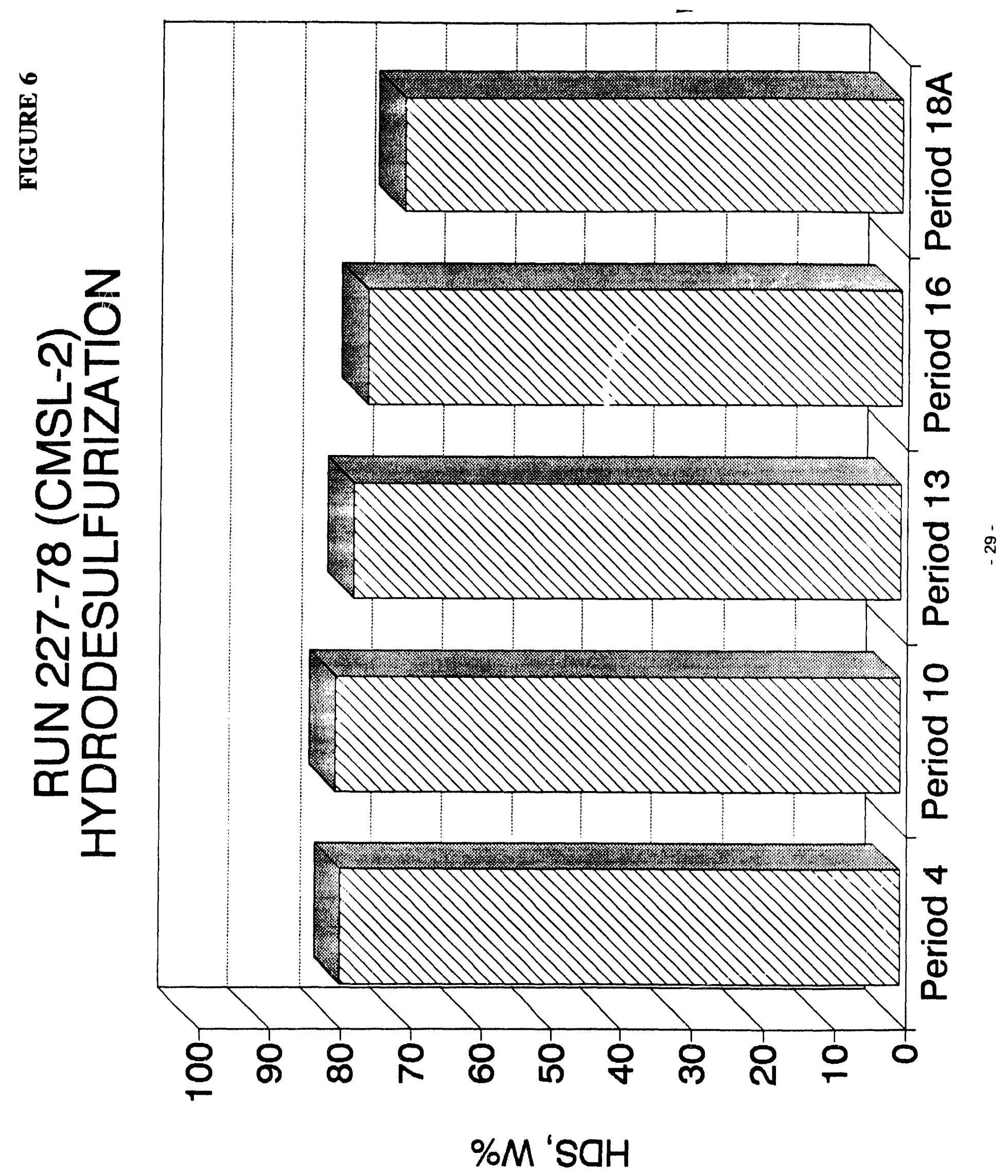




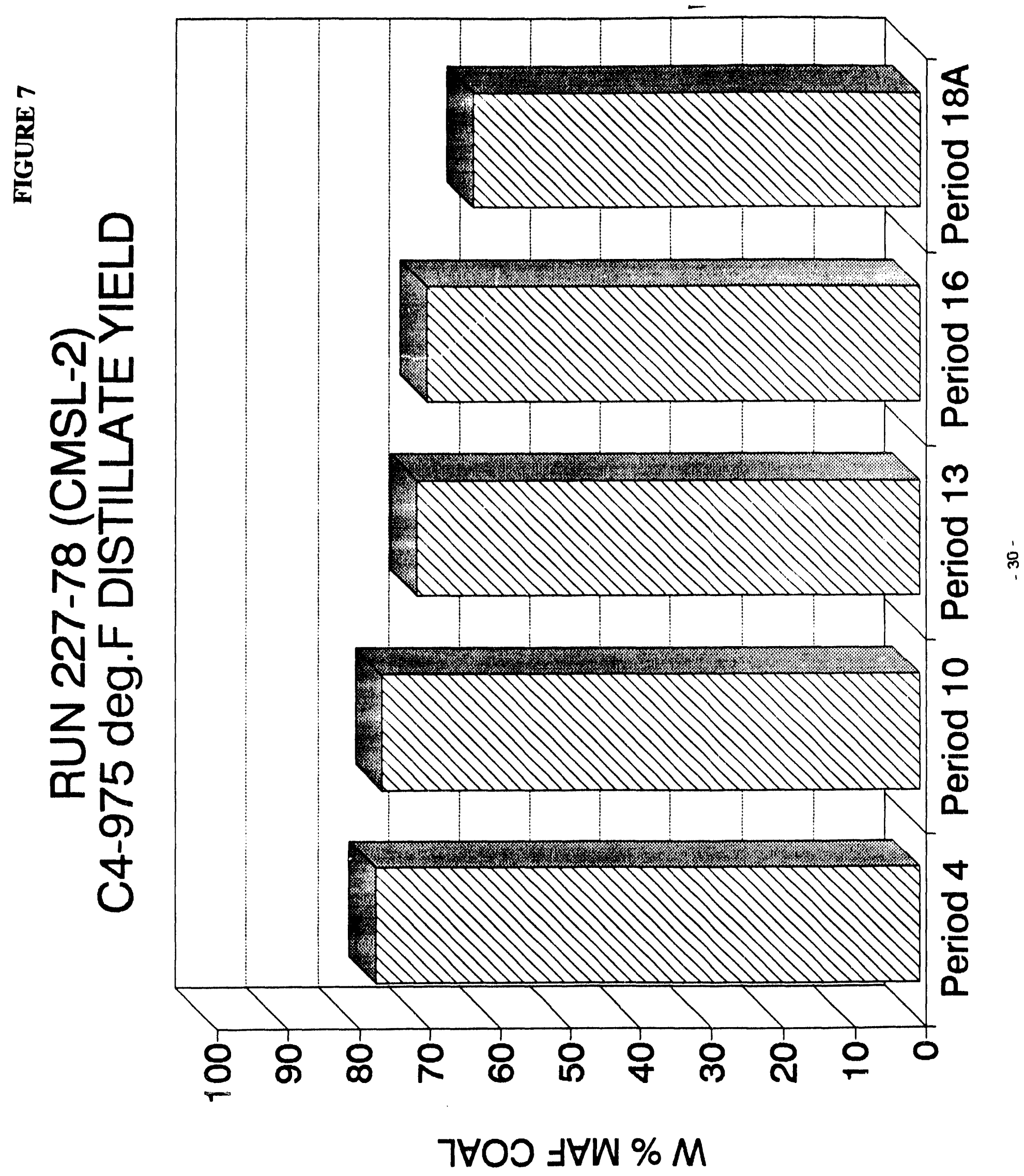


$\underbrace{\infty}_{2}$

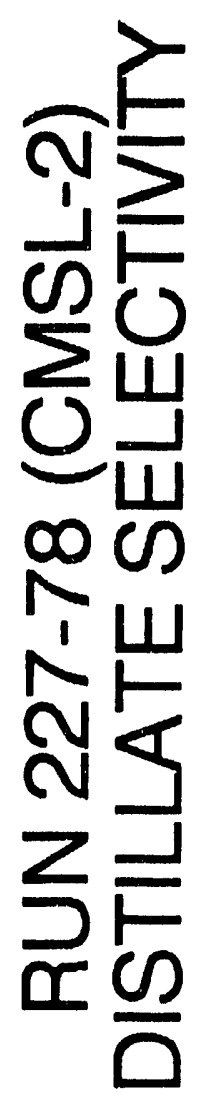

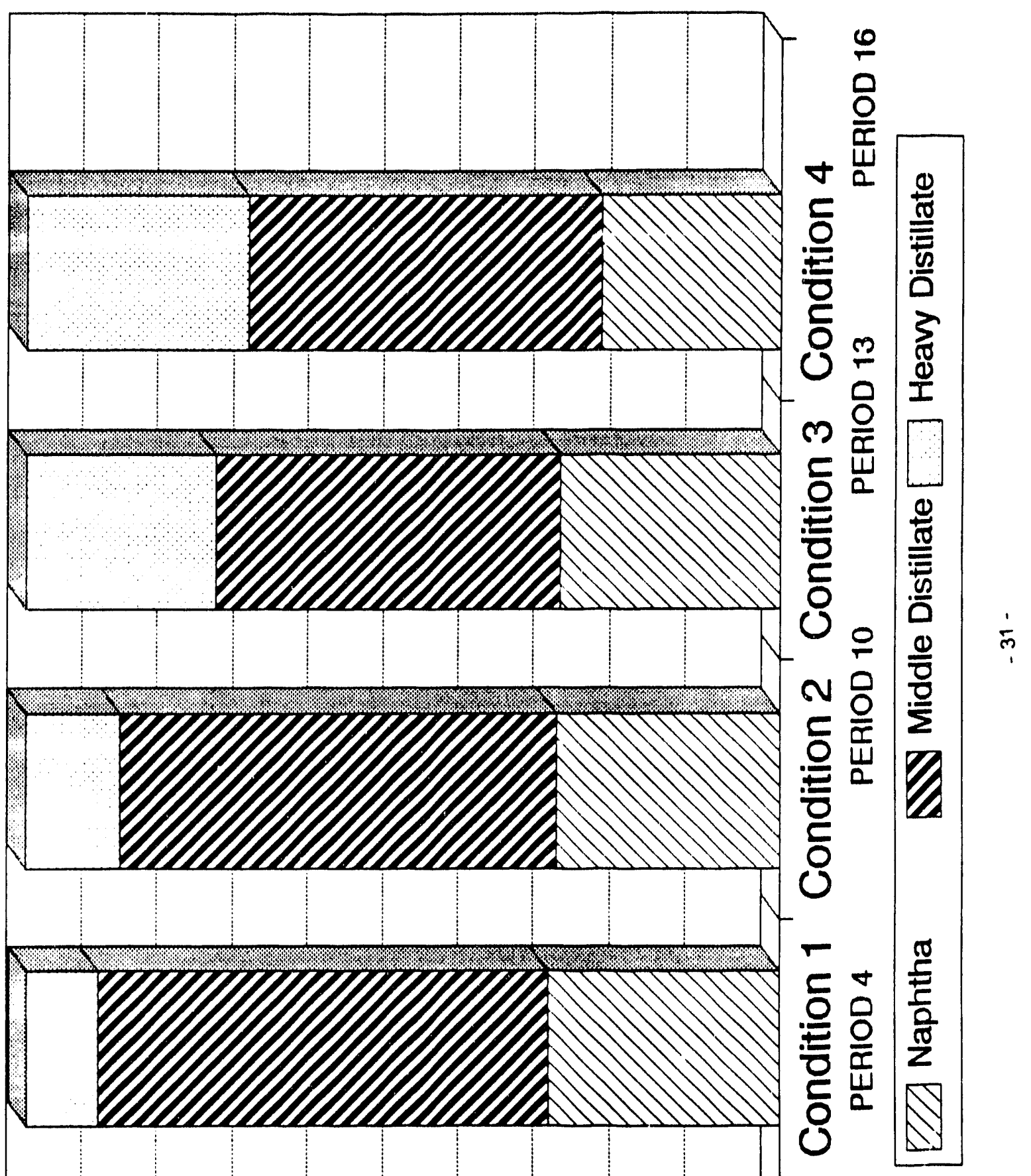




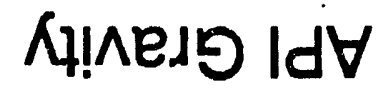

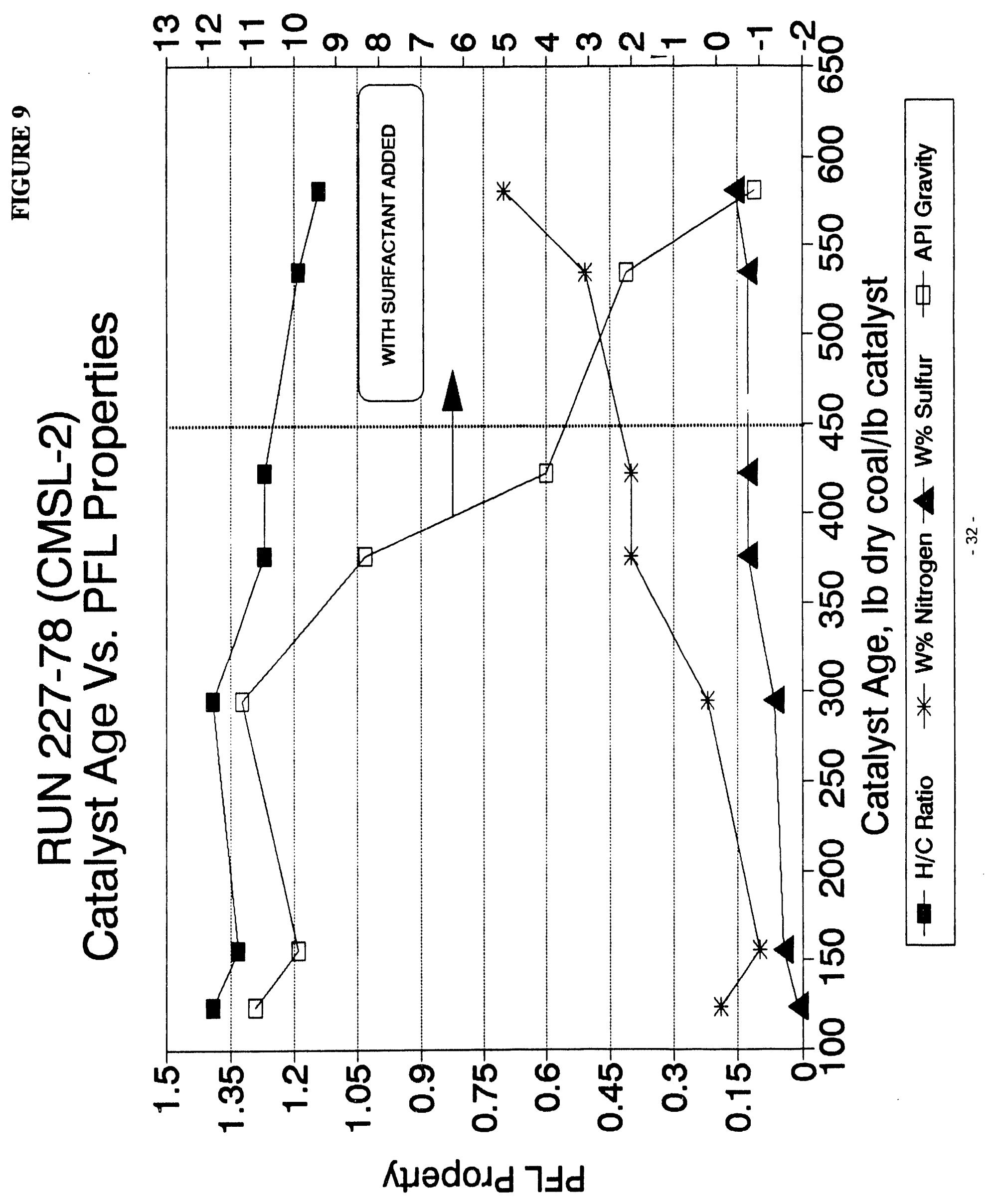




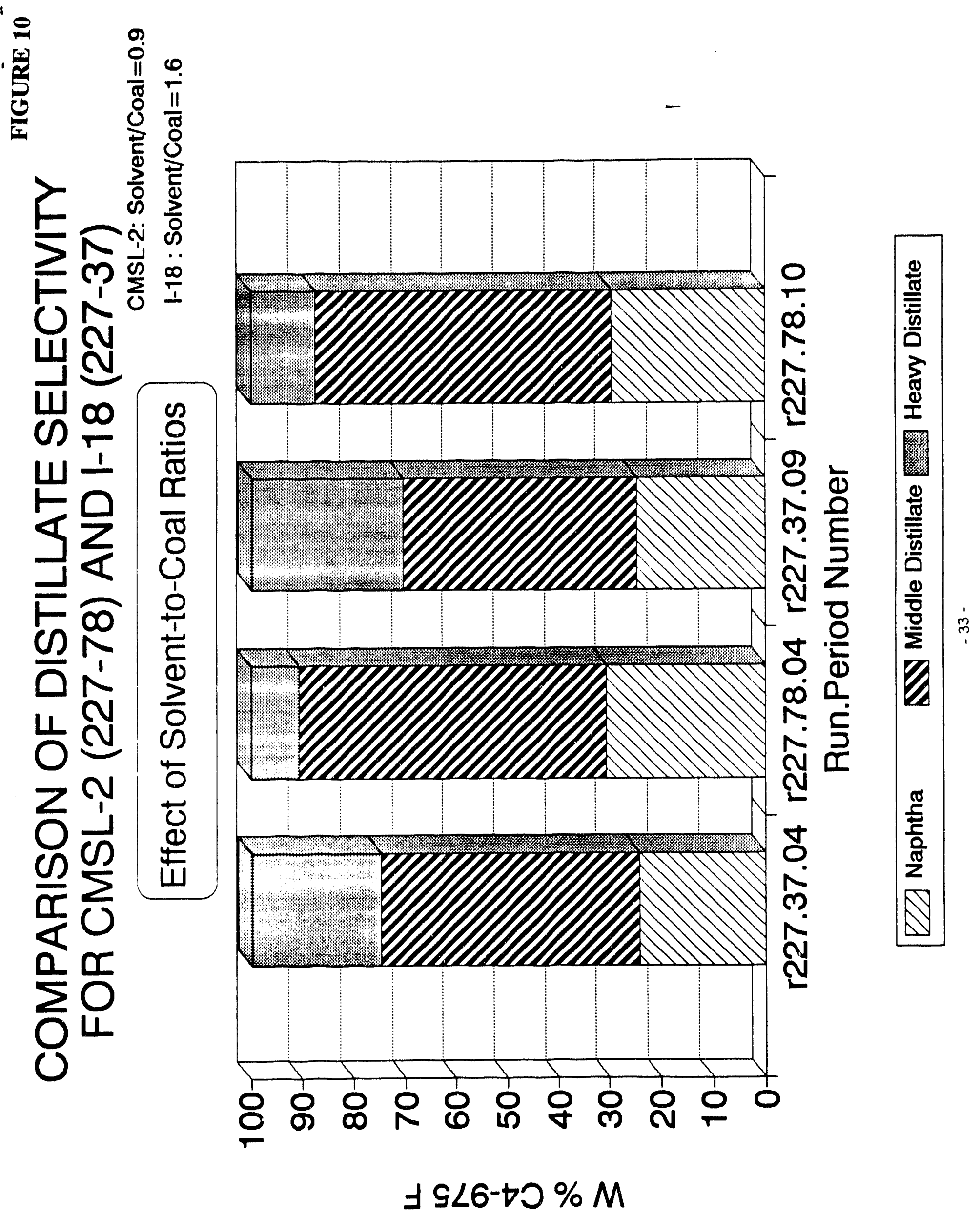




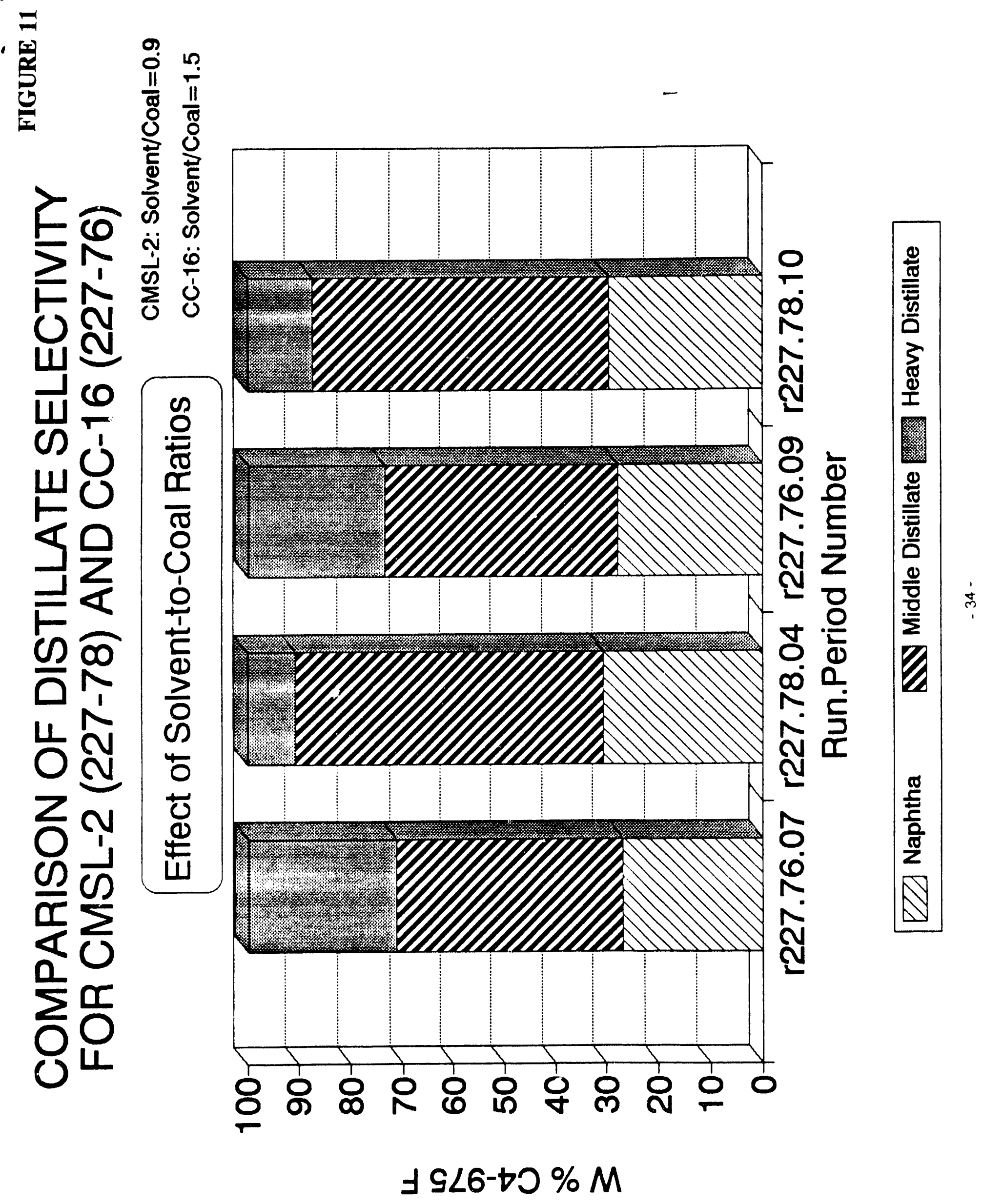


匀

崩

突号

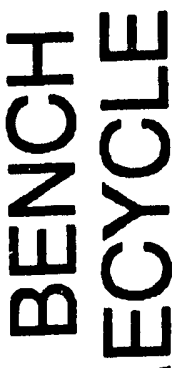

山ᄄ

殅岁

F心

岁立

Z立

जO

品

4

0

$\sum$

0

0

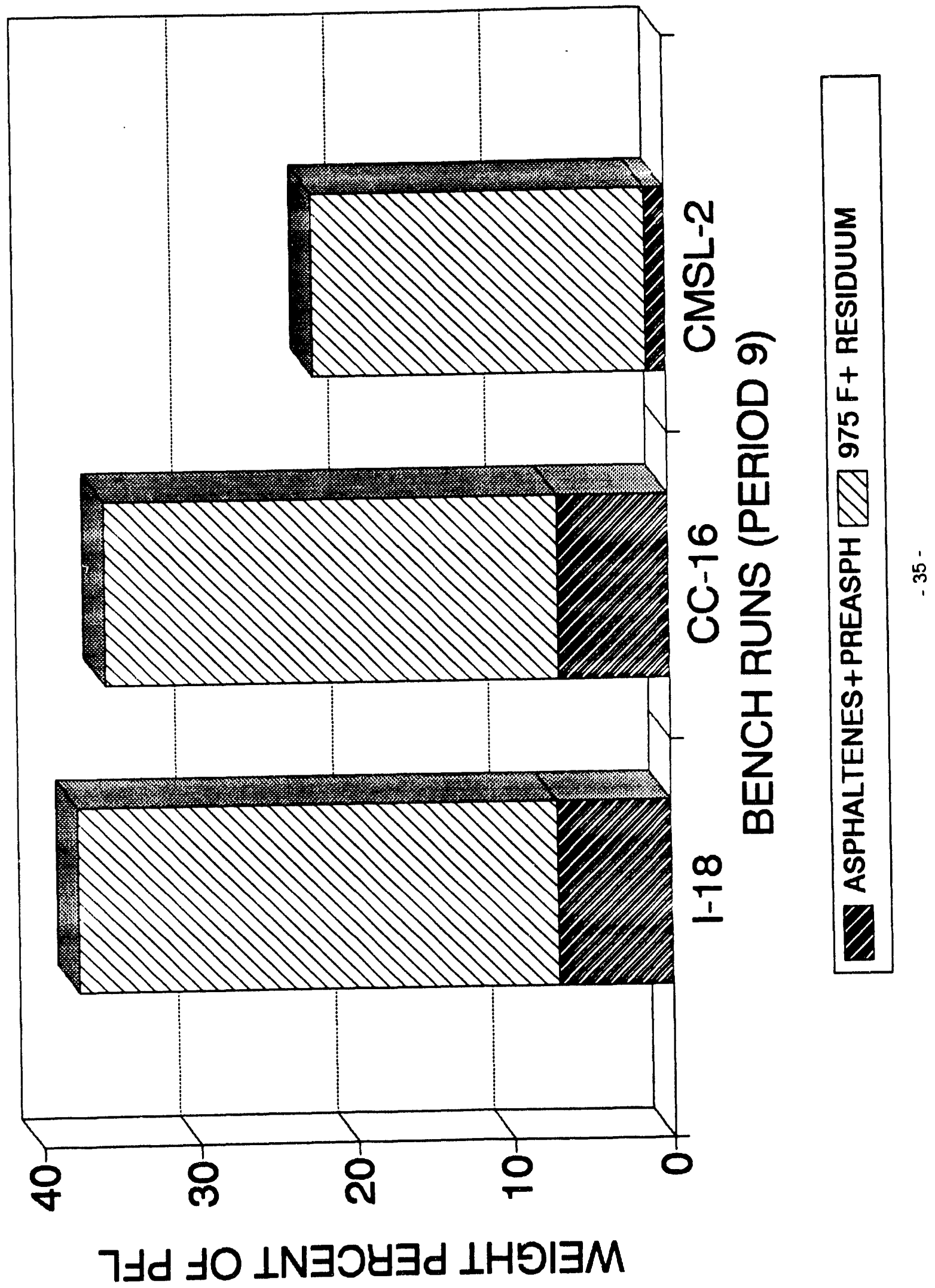




\section{TASK 3 - BENCH-SCALE STUDIES}

\section{RUN CMSL-3 - SYNTHESIS GAS AS REDUCING GAS}

\section{Objective}

To evaluate the effect of reaction severity on the dissolution of Black Thunder Mine coal under a synthesis gas atmosphere (and water-gas shift conditions) in a two-stage mode of operation with an interstage separator.

\section{Rationale}

In the presence of a suitable catalyst/promoter, a mixture of $\mathrm{CO} / \mathrm{H}_{2} \mathrm{O} / \mathrm{H}_{2}$ is very effective in solubilizing high oxygen-containing low rank coals at relatively mild severity conditions of below $400^{\circ} \mathrm{C}$ and 30 minutes of residence time. The ability to use synthesis gas $\left(\mathrm{CO} / \mathrm{H}_{2}\right)$, coming directly from a gasifier, rather than high purity hydrogen, can provide additional savings in the coal liquefaction operating costs.

\section{Technical Objectives}

1. To evaluate the operability of an interstage separator using pure hydrogen as reducing gas for both stages.

2. To evaluate the effect of first stage temperature with synthesis gas as reducing gas.

3. To evaluate the impact of space velocity on process performance with synthesis gas as reducing gas in the first stage.

\section{Run Plan}

The Run Plan for CMSL-3, consisting of four operating Conditions is shown in Table 12. The results obtained from this Bench Run, CMSL-3, will be presented in the next quarterly report. 
Table 12

Run Plan for the Bench Run CMSL-3

BLACK THUNDER COAL (25 W\% moisture)

1ST STAGE ADDITIVE: AMMONIUM HEPTAMOLYBDATE, 1500 ppm Mo per dry coal feed.

2ND STAGE CATALYST: SHELL-317 Ni/Mo 1/32" Extrudates

Back Pressure: 2500 psig.

Condition

Periods

Reducing Gas $\left(\mathrm{CO} / \mathrm{H}_{2}\right)$

1st Stage

2nd Stage

Sulfur Additive

TNPS (1st Stage)

$\mathrm{H}_{2} \mathrm{~S}$ (2nd Stage)

Space Velocity, (2 nd stage)

lb dry coal/hr/ft cat.

Temperatures, ${ }^{\circ} \mathrm{F}$

1st Stage

Interstage Separator

2nd Stage

Hot Separator

Atmospheric Still

Recycle Solvent/Coal Ratio
1

$1-5$

$0 / 100$

$0 / 100$
2

6-9

3

10-12

4

13-16

$75 / 25$

$75 / 25$

$0 / 100$

$75 / 25$

$0 / 100$
$1 \mathrm{~S} \mathrm{W \%}$ of dry coal...............

$3 \mathrm{~S} \mathrm{W \%}$ of dry coal.

44

44

44

67

730

730

800

600

550

730

730

800

600

550

1.2

1.2

1.2

1.2 


\section{TASK 4 - TECHNICAL ASSESSMENT}

Two screening studies have been initiated on a preliminary basis during this quarter. These include : (i) to examine the economics of using dispersed catalyst vs. supported catalyst in the first stage reactor, and (ii) to examine the cost impact of using syngas, instead of pure hydrogen, in the first stage reactor for liquefaction of low-rank coals.

\section{TASK 5 - PROJECT MANAGEMENT}

The next bench-run (the one after the upcoming CMSL-3) in this program, CMSL-4, is planned for sometime during December 1993, after the operation of the upcoming PDU run, scheduled in October 1993. 

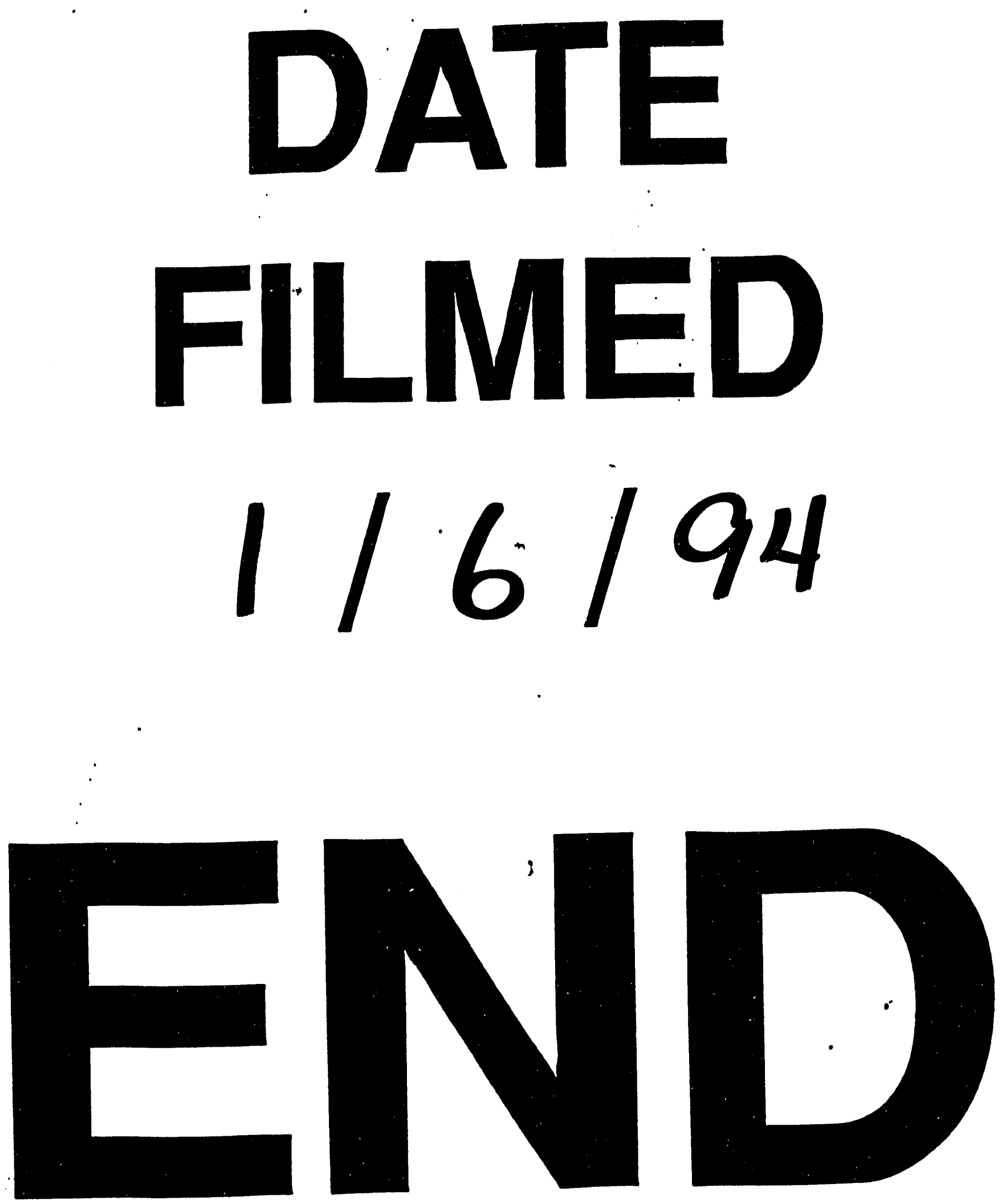
